Article

\title{
Activity and Thermal Stability of Cobalt(II)-Based Olefin Polymerization Catalysts Adorned with Sterically Hindered Dibenzocycloheptyl Groups
}

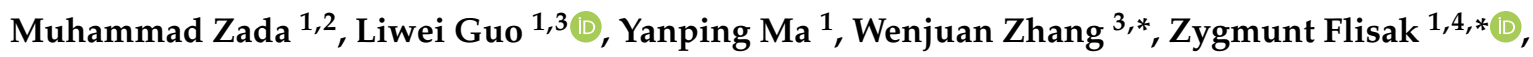 \\ Yang Sun ${ }^{1}$ and Wen-Hua Sun $1,2, *$ (D) \\ 1 Key Laboratory of Engineering Plastics and Beijing National Laboratory for Molecular Science, Institute of \\ Chemistry, Chinese Academy of Sciences, Beijing 100190, China; mzada17@iccas.ac.cn (M.Z.); \\ mrliwei_guo@163.com (L.G.); myanping@iccas.ac.cn (Y.M.); sy0471103@iccas.ac.cn (Y.S.) \\ 2 CAS Research/Education Center for Excellence in Molecular Sciences, University of Chinese Academy of \\ Sciences, Beijing 100049, China \\ 3 Beijing Key Laboratory of Clothing Materials R\&D and Assessment, Beijing Engineering Research Center of \\ Textile Nanofiber, School of Materials Science and Engineering, Beijing institute of Fashion Technology, \\ Beijing 100029, China \\ 4 Faculty of Chemistry, University of Opole, Oleska 48, 45-052 Opole, Poland \\ * Correspondence: zhangwj@bift.edu.cn (W.Z.); zgf@uni.opole.pl (Z.F.); whsun@iccas.ac.cn (W.-H.S.); \\ Tel.: +86-10-6255-7955 (W.-H.S.)
}

Academic Editor: Giovanni Ricci

Received: 3 May 2019; Accepted: 24 May 2019; Published: 25 May 2019

\begin{abstract}
Five examples of unsymmetrical 2-(2,4-bis(dibenzocycloheptyl)-6-methylphenyl-imino)ethyl)6-(1-(arylyimino)ethyl)pyridine derivatives ( $\operatorname{aryl}=2,6-\mathrm{Me}_{2} \mathrm{C}_{6} \mathrm{H}_{3}$ in $\mathbf{L 1}$; 2,6- $\mathrm{Et}_{2} \mathrm{C}_{6} \mathrm{H}_{3}$ in $\mathbf{L 2}$; 2,6-i- $\mathrm{Pr}_{2} \mathrm{C}_{6} \mathrm{H}_{3}$ in $\mathbf{L 3} ; 2,4,6-\mathrm{Me}_{3} \mathrm{C}_{6} \mathrm{H}_{2}$ in $\mathbf{L} 4$ and 2,6-Et $-4-\mathrm{MeC}_{6} \mathrm{H}_{2}$ in $\mathbf{L} 5$ ) were prepared and characterized. Treatment with $\mathrm{CoCl}_{2}$ offered the corresponding cobalt precatalysts $\mathrm{Co1}-\mathrm{Co}$, which were characterized by FT-IR and NMR spectroscopy as well as elemental analysis. The molecular structures of Co3 and Co4 determined by single crystal X-ray diffraction revealed distorted square pyramidal geometries with $\tau_{5}$ values of $0.052-0.215$. Activated with either MAO or MMAO, the precatalysts displayed high activities in ethylene polymerization, where Co1 with the least bulky substituents exhibited a peak activity of $1.00 \times 10^{7} \mathrm{~g} \mathrm{PE} \mathrm{mol}^{-1}(\mathrm{Co}) \mathrm{h}^{-1}$ at $60^{\circ} \mathrm{C}$. With MAO as a cocatalyst, the activity was reduced only by one order of magnitude at $90^{\circ} \mathrm{C}$, which implies thermally stable active sites. The polymerization product was highly linear polyethylene with vinyl end groups. Co3 with the most sterically hindered active sites was capable of generating polyethylene of high molecular weight, reaching $6.46 \times 10^{5} \mathrm{~g} \mathrm{~mol}^{-1}$. Furthermore, high melting point and unimodal molecular weight distribution were observed in the resulting polyethylene. It must be stressed that the thermal stability of the catalyst and the molecular weight of the obtained polyethylene attain the highest values reported for the unsymmetrical 2,6-bis(imino)pyridylcobalt (II) chloride precatalysts.
\end{abstract}

Keywords: Dibenzocycloheptyl group; 2,6-bis(imino)pyridylcobalt(II) chloride precatalysts; thermal stability; high molecular-weight saturated/unsaturated polyethylene

\section{Introduction}

The effective design of late transition metal precatalysts for ethylene polymerization and oligomerization has attracted considerable attention over the last twenty years. The contributing factors are the ease of preparation and capability to generate diverse polymers, including highly linear and highly branched polyethylenes with varied contents of unsaturated groups, as well as waxes [1-5]. The initial reports on the bis(imino)pyridyliron(II) or cobalt(II) chloride precatalysts in ethylene 
polymerization [1,2] were fundamental to subsequent investigations focusing on the relationship between the structure, productivity and thermal stability of precatalysts. In these works, selection of the metal and variations in the ligand framework were carried out in the catalyst design phase and determined the physical properties and applications of the polymer [6,7]. For example, in contrast to branched polyethylenes generated by $\mathrm{Ni}$ (II) or Pd(II) systems [1,2,6,7], highly linear polyethylene is usually obtained by using Fe(II) or Co(II) catalysts. Successive modifications of the substituents attached to the existing bis(imino)pyridine framework aimed at improving the catalytic performance and thermal stability of the corresponding metal complexes [1,2,6-8] and usually modulated steric and electronic properties of the ligand [1,2,9-18]. As a result, novel iron and cobalt precatalysts bearing the bis(imino)pyridine framework were developed [8-20], in which the cycloalkyl rings were fused with the pyridine moiety [21-35]. In particular, the benzhydryl group which exerts significant steric hindrance, combined with the electron withdrawing or the electron donating substituents led to highly active and thermally stable precatalysts (Scheme 1, A) [36-42] that surpass the systems reported before [1,2]. The precatalysts bearing the ligands with the benzhydryl groups at the ortho-positions along with the electron withdrawing substituents at the para- position in one of the aryl rings attached to the imine nitrogen atom exhibited good thermal stability at the expense of slightly lower activity [43]. Within this series of precatalysts, fluorinated benzhydryl groups offered the highest thermal stability [44]. The incorporation of a single benzhydryl substituent at the ortho- position in one of the aryl rings attached to the imine nitrogen atom together with the electron donating methyl substituents at the remaining ortho- and para- positions in the 2,6-bis(imino)pyridine ligand improved the activity of the iron precatalyst with respect to the cobalt system (Scheme 1, B) [39]. Moreover, adding another benzhydryl substituent at the para-position within the same aryl group enhanced the catalytic performance and thermal stability of 2,6-bis(imino)pyridine-based iron and cobalt precatalysts, and influenced the molecular weight of polyethylene (Scheme 1, C) [38,45]. The corresponding precatalysts with the fluorinated benzhydryl substituents have also been investigated in ethylene polymerization, displaying pronounced activity and enhanced thermal stability [46]. In addition to that, cobalt bis(imino)pyridine precatalysts bearing the 2,4-dibenzhydrylnaphthyl moiety attached to the imino nitrogen atom generate highly linear polyethylene with the vinyl end groups $[13,41]$. In contrast to the unsymmetrically substituted systems listed above, the 2,6-bis(imino)pyridyliron or cobalt precatalysts bearing two benzhydryl substituents attached to each aryl rings offer enhanced thermal stability, but the activity in ethylene polymerization is somewhat compromised [47].

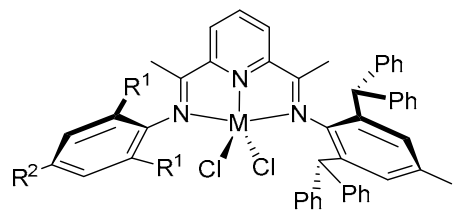

A $(\mathrm{M}=\mathrm{Fe}, \mathrm{Co})$

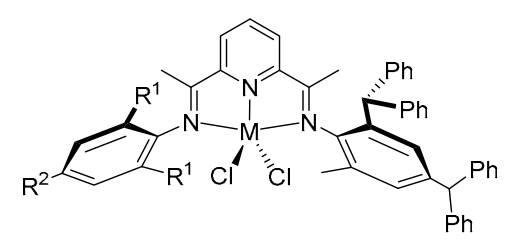

$\mathrm{C}(\mathrm{M}=\mathrm{Fe}, \mathrm{Co})$

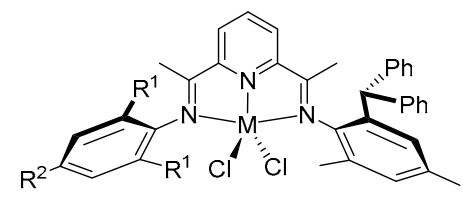

$\mathbf{B}(\mathrm{M}=\mathrm{Fe}, \mathrm{Co})$

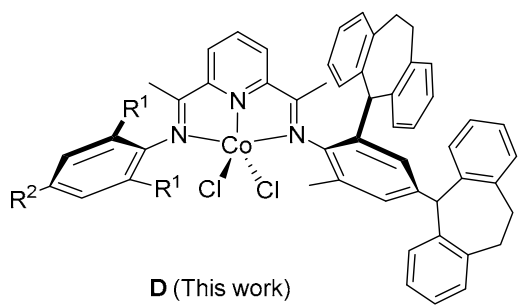

Scheme 1. A-D: Structural variations in the bis(imino)pyridine-iron and cobalt precatalysts.

Recently, our research group has focused on the ligands, where single and double carbocyclic units of different size were fused with the pyridine ring, and synthesized the corresponding cobalt, iron and chromium complexes in order to investigate the effect of these modifications on the catalytic performance, thermal stability and the properties of the resultant polyethylene [8,48-50]. 
In order to further refine our understanding of the action of bulky substituents on the thermal stability of precatalysts, polymer productivity and its molecular weight, we turned our attention to dibenzocycloheptyl substituents attached to one of the aryl rings. In this contribution, we disclose the ligand design with 2,4-bis(dibenzocycloheptyl)-6-methylphenylamine, which serves as a starting point to prepare the unsymmetrical 2-(1-(2,4-bis(dibenzocycloheptyl)-6-methylphenylimino)ethyl) -6-(1-(arylimino)ethyl)pyridine and the corresponding cobalt(II) chloride precatalysts (Scheme 1, D). The complete synthetic procedure and characterization of ligands together with the corresponding cobalt precatalysts, as well as the catalytic performance in ethylene polymerization, thermal stability and the properties of the resultant polymer are reported.

\section{Results}

\subsection{Synthesis and Characterization}

2,4-bis(Dibenzocycloheptyl)-6-methylaniline is prepared in a good yield according to the literature method [51-55]. The condensation reaction with one molar equivalent of 2,6-diacetylpyridine generates the monoketone derivative, 2-acetyl-6-(1-(2,4-bis(dibenzocyclo-heptyl)-6-methylphenylimino)ethyl)pyridine. Subsequent reactions with the corresponding anilines lead to a series of 2-(1-(2,4-bis(dibenzocycloheptyl)-6methylphenylimino)ethyl)-6-(1-(arylimino)-ethyl)pyridine ligands (L1-L5); $\left\{\operatorname{aryl}=2,6-\mathrm{Me}_{2} \mathrm{C}_{6} \mathrm{H}_{3}\right.$ (L1), 2,6- $\mathrm{Et}_{2} \mathrm{C}_{6} \mathrm{H}_{3}$ (L2), 2,6- ${ }^{i} \mathrm{Pr}_{2} \mathrm{C}_{6} \mathrm{H}_{3}$ (L3), 2,4,6- $-\mathrm{Me}_{3} \mathrm{C}_{6} \mathrm{H}_{2}$ (L4) and 2,6- $\mathrm{Et}_{2}-4-\mathrm{MeC}_{6} \mathrm{H}_{2}$ (L5)\}. Upon treatment with $\mathrm{CoCl}_{2}$, the corresponding precatalysts $\mathrm{Co1}-\mathrm{Co} 5$ are obtained (Scheme 2).
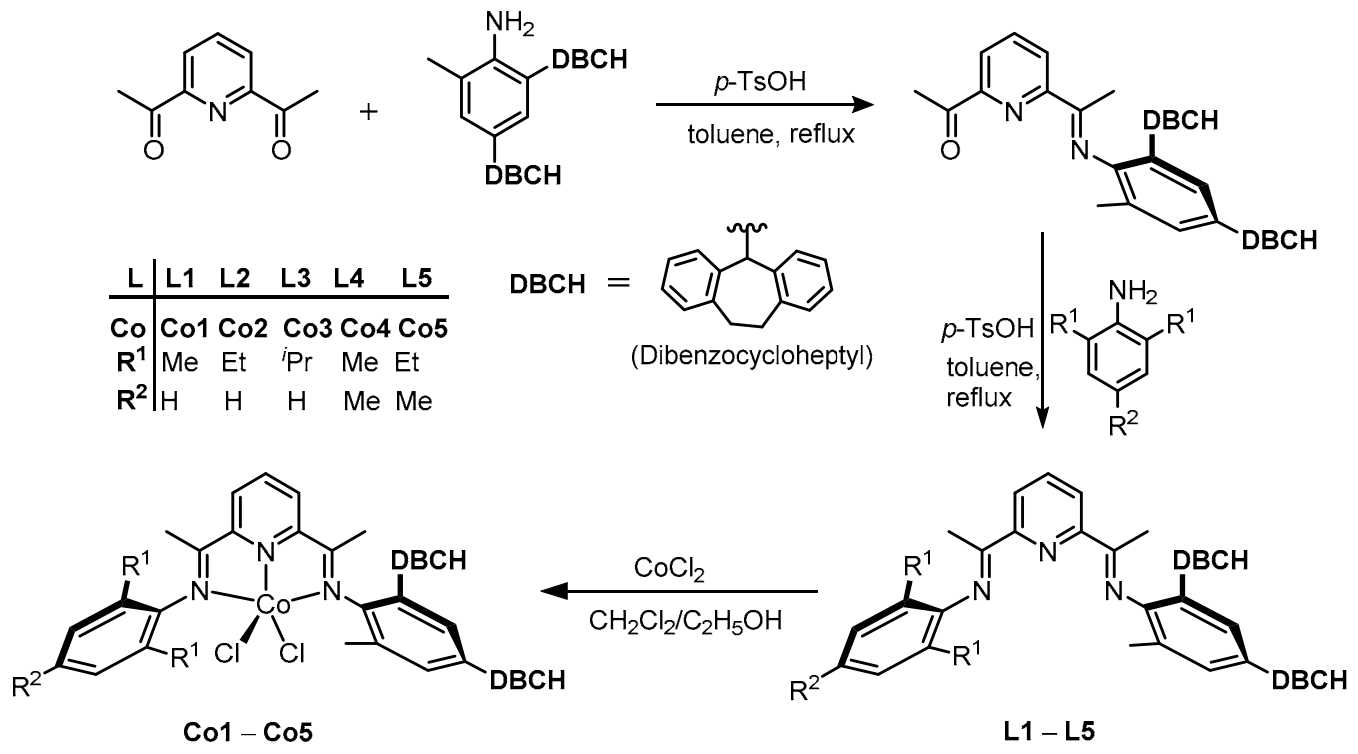

Scheme 2. Synthesis of ligands (L1-L5) and the corresponding cobalt(II) chloride complexes (Co1-Co5).

All the organic compounds and cobalt precatalysts mentioned above were characterized by FT-IR spectroscopy, NMR spectroscopy and elemental analysis. The representative complexes Co3 and Co4 were the subject of single-crystal X-ray diffraction analysis. In the FT-IR spectra of the complexes, the wavenumbers corresponding to the stretching vibrations of the $\mathrm{C}=\mathrm{N}_{\text {imine }}$ bonds observed in the range of 1624-1625 $\mathrm{cm}^{-1}$ are lower, comparing with the respective ligands $\left(1640-1649 \mathrm{~cm}^{-1}\right)$. This finding reveals the effective coordination of the metal center and the ligand donor atoms, as reported earlier [36,46]. The ${ }^{1} \mathrm{H}-\mathrm{NMR}$ spectra of the cobalt precatalysts were recorded in deuterated dichloromethane $\mathrm{CD}_{2} \mathrm{Cl}_{2}$ at ambient temperature (see Supporting Information, Figures S1-S5). The characteristic peaks were assigned by comparison with the spectra of related bis(imino)pyridyl precatalysts $[18,56,57]$. Each spectrum reveals the unsymmetrical nature; for example, Co1 shows two distinct signals for the m-pyridyl protons, which appear downfield with the chemical shifts of 113.26 and 110.26 ppm, respectively; each with 
the relative area of 1 and the $p$-pyridyl proton with the chemical shift of 37.57 ppm and the area of 1 . Moreover, the peaks for the methyl groups attached to the aryl rings at the ortho-position were observed upfield with chemical shifts of -25.35 to $-29.44 \mathrm{ppm}$ and the acetyl protons downfield at 1.22 to $1.54 \mathrm{ppm}$, respectively; each with an area of 3 . The remaining spectra are similar; for example, in Co4 and Co5, distinct peaks are observed for the methyl protons attached to the aryl ring at the para-position with the chemical shifts of 17.56 and 18.63 ppm, respectively. The elemental analysis of all ligands and complexes was consistent with their formulae. In addition, the molecular structure of $\mathbf{C o 3}$ and $\mathbf{C o} 4$ were determined by single-crystal X-ray diffraction analysis.

\subsection{X-Ray Crystallographic Studies}

Single crystals of $\mathrm{Co3}$ and Co4 suitable for the X-ray determinations were grown by the slow diffusion of diethyl ether into a solution of the corresponding complex in dichloromethane. During structural refinement two independent molecules (Aand $B$ ) were obtained; only molecule $A$ is displayed in Figures 1 and 2. The selected bond lengths and angles are collected in Table 1 (for molecule $A$ ) and in Table S1 (for molecule $\boldsymbol{B}$ ). The complexes comprise a single cobalt center bound to the 2,6-(bisarylimino)pyridine chelating ligand and two halide ligands, resulting in a distorted square pyramidal geometry. This geometry is further rationalized by the tau value $\left(\tau_{5}\right)$ which is defined by the following equation:

$$
\tau_{5}=(\beta-\alpha) / 60
$$

where $\beta$ is the largest angle and $\alpha$ is the second largest angle in the coordination sphere (Table 2); a perfect square pyramid and a perfect trigonal bipyramid are indicated by the tau values of zero and one, respectively [58-60]. The nitrogen atoms (N1, N2 and N3) and one chlorine atom $\mathrm{Cl}(1)$ form the basal plane and the second chlorine atom $\mathrm{Cl}(2)$ occupies the apical position. The cobalt atoms lie out of the N1, N2, N3 plane in each complex with the dihedral angles of 89.14-88.53 ${ }^{\circ}(A)$, and 89.56-88.98 (B). Similar observations have been reported for other bis(imino)pyridine complexes [36-46]. Different substitution patterns of both aryl rings attached to the imine nitrogen atoms and varied steric hindrance around this atom are reflected by the modest imbalance in the corresponding $\mathrm{Co}-\mathrm{N}_{\text {imine }}$ bond lengths,

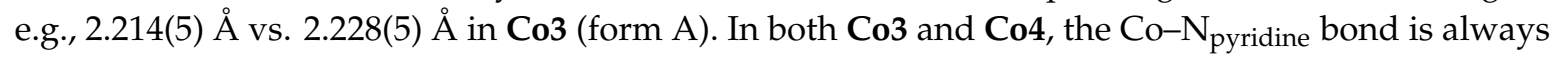
stronger than any of the $\mathrm{Co}-\mathrm{N}_{\text {imine }}$ bonds [36-42,46]. The $\mathrm{N}(2)-\mathrm{C}(8)$ bond lengths in both complexes reveal the typical features of a $\mathrm{C}=\mathrm{N}$ bond.

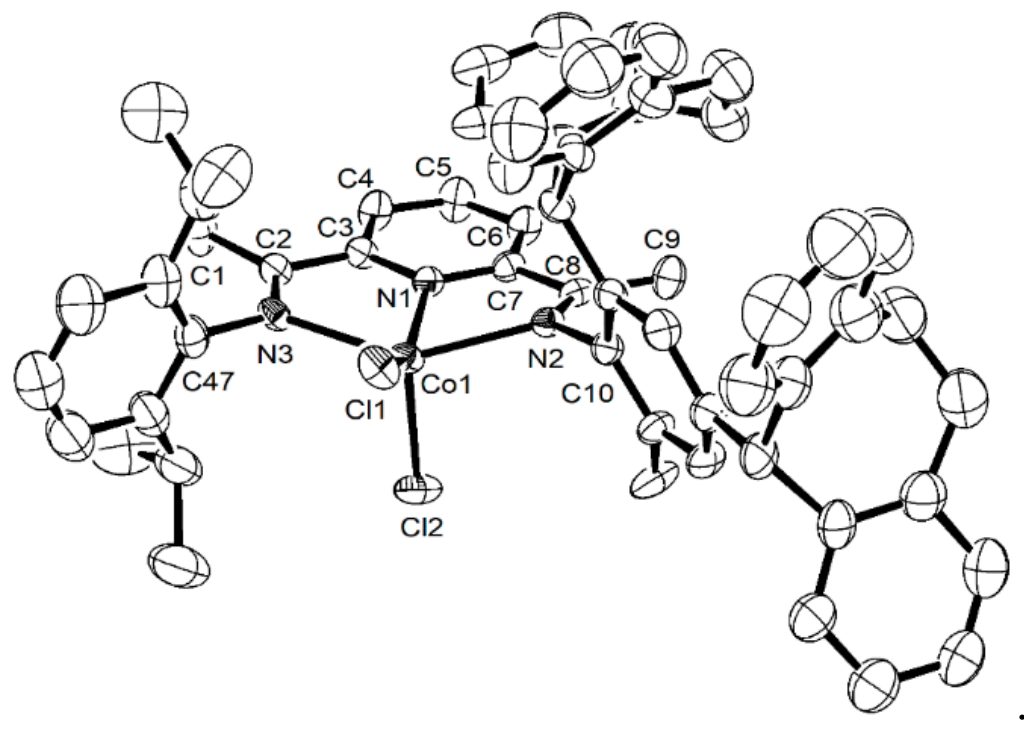

Figure 1. ORTEP diagram of Co3 with thermal ellipsoids set at the probability level of $30 \%$. All hydrogen atoms and another molecule of the complex have been omitted for clarity. 


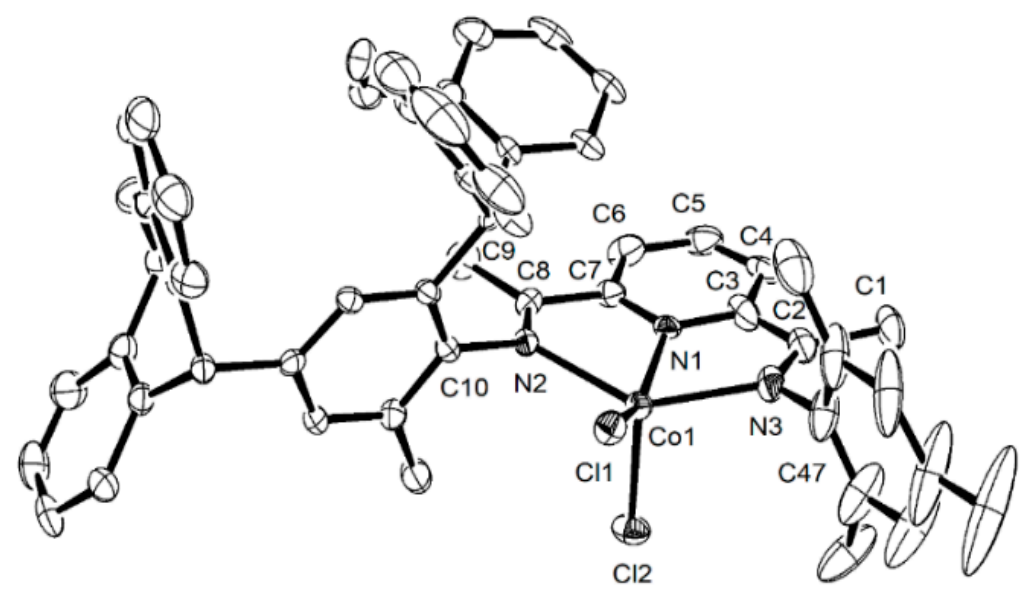

Figure 2. ORTEP diagram of Co4 with thermal ellipsoids set at the probability level of $30 \%$. All hydrogen atoms and another molecule of the complex have been omitted for clarity.

Table 1. Selected bond lengths $(\AA)$ and angles $\left(^{\circ}\right)$ for Co3 and Co4.

\begin{tabular}{ccc}
\hline & Co3 & Co4 \\
\hline Bond Lengths (Å) & Molecule A & Molecule A \\
\hline $\mathrm{Co}(1)-\mathrm{N}(1)$ & $2.043(5)$ & $2.033(7)$ \\
$\mathrm{Co}(1)-\mathrm{N}(2)$ & $2.214(5)$ & $2.188(6)$ \\
$\mathrm{Co}(1)-\mathrm{N}(3)$ & $2.228(5)$ & $2.191(7)$ \\
$\mathrm{Co}(1)-\mathrm{Cl}(1)$ & $2.2481(18)$ & $2.251(2)$ \\
$\mathrm{Co}(1)-\mathrm{Cl}(2)$ & $2.3047(18)$ & $2.308(2)$ \\
$\mathrm{N}(2)-\mathrm{C}(10)$ & $1.437(7)$ & $1.463(9)$ \\
$\mathrm{N}(3)-\mathrm{C}(47)$ & $1.453(8)$ & $1.428(13)$ \\
$\mathrm{N}(1)-\mathrm{C}(3)$ & $1.345(7)$ & $1.348(13)$ \\
$\mathrm{N}(1)-\mathrm{C}(7)$ & $1.338(7)$ & $1.357(12)$ \\
$\mathrm{N}(2)-\mathrm{C}(8)$ & $1.286(7)$ & $1.289(10)$ \\
$\mathrm{N}(3)-\mathrm{C}(2)$ & $1.274(7)$ & $1.289(12)$ \\
\hline & Bond Angles () & \\
\hline $\mathrm{N}(1)-\mathrm{Co}(1)-\mathrm{N}(2)$ & $74.25(17)$ & $73.90(3)$ \\
$\mathrm{N}(1)-\mathrm{Co}(1)-\mathrm{N}(3)$ & $74.85(17)$ & $74.10(3)$ \\
$\mathrm{N}(2)-\mathrm{Co}(1)-\mathrm{N}(3)$ & $144.51(17)$ & $142.10(3)$ \\
$\mathrm{N}(1)-\mathrm{Co}(1)-\mathrm{Cl}(1)$ & $147.63(14)$ & $150.90(2)$ \\
$\mathrm{N}(2)-\mathrm{Co}(1)-\mathrm{Cl}(1)$ & $98.53(13)$ & $99.28(18)$ \\
$\mathrm{N}(3)-\mathrm{Co}(1)-\mathrm{Cl}(1)$ & $98.24(13)$ & $98.80(2)$ \\
$\mathrm{N}(2)-\mathrm{Co}(1)-\mathrm{Cl}(2)$ & $99.45(13)$ & $99.87(18)$ \\
$\mathrm{N}(3)-\mathrm{Co}(1)-\mathrm{Cl}(2)$ & $101.00(13)$ & $102.76(18)$ \\
$\mathrm{Cl}(1)-\mathrm{Co}(1)-\mathrm{Cl}(2)$ & $115.82(7)$ & $113.91(9)$ \\
$\mathrm{N}(1)-\mathrm{Co}(1)-\mathrm{Cl}(2)$ & $96.54(14)$ & $95.10(2)$ \\
$\mathrm{C}(10)-\mathrm{N}(2)-\mathrm{Co}(1)$ & $122.50(4)$ & $124.4(5)$ \\
$\mathrm{C}(47)-\mathrm{N}(3)-\mathrm{Co}(1)$ & $124.00(4)$ & $124.80(7)$ \\
\hline
\end{tabular}

Table 2. Distance of the Co atom from the N1, N2, N3 plane, angles in the coordination sphere and the corresponding tau values $\left(\tau_{5}\right)$ for $\mathrm{Co} 3$ and Co4.

\begin{tabular}{cccccc}
\hline Complex & Molecule & Co distance, $\AA$ & $\boldsymbol{\alpha}^{\circ}{ }^{\circ}$ & $\boldsymbol{\beta}^{\circ}{ }^{\circ}$ & $\boldsymbol{\tau}_{5}{ }^{\mathbf{a}}$ \\
\hline Co3 & $A$ & 0.543 & 144.51 & 147.63 & 0.052 \\
& $B$ & 0.513 & 141.15 & 154.04 & 0.215 \\
Co4 & $A$ & 0.532 & 142.10 & 150.90 & 0.147 \\
& $B$ & 0.806 & 142.70 & 150.70 & 0.133 \\
\hline
\end{tabular}

${ }^{\text {a }}$ As defined by Equation (1). 


\subsection{Evaluation of Cocatalyst}

Previous studies on iron and cobalt bis(iminopyridine) catalysts indicated that methyl- aluminoxane (MAO) and modified methylaluminoxane (MMAO) are more effective cocatalysts compared with alkylaluminum reagents in ethylene polymerization [11,12,36-42]. In order to investigate the catalytic performance of the cobalt precatalysts toward ethylene polymerization, Co1 was selected as the precatalyst for initial screening and the reaction conditions such as temperature, $\mathrm{Al} / \mathrm{Co}$ ratio and time were systematically varied under ethylene pressure of $10 \mathrm{~atm}$ using methylaluminoxane (MAO) or modified methylaluminoxane (MMAO) as cocatalysts. Then the catalytic performance of the remaining cobalt precatalysts Co2-Co5 was investigated at the conditions established before. Additionally, the catalytic activity of precatalyst Co1 at ethylene pressure of 5 and $1 \mathrm{~atm}$ was also determined. The molecular weight $\left(M_{\mathrm{w}}\right)$ and molecular weight distribution $\left(M_{\mathrm{w}} / M_{\mathrm{n}}\right)$ of the resultant polyethylene were ascertained by gel permeation chromatography and the melting temperature was measured by differential scanning calorimetry (DSC). The microstructure of typical polyethylene samples was analyzed by the high-temperature NMR $\left({ }^{1} \mathrm{H} /{ }^{13} \mathrm{C}\right)$ spectroscopy.

\subsubsection{Ethylene Polymerization with (Co1-Co5)/MAO}

The results of polymerization tests carried out for Co1 in toluene under ethylene pressure of $10 \mathrm{~atm}$ are summarized in Table 3. The polymerization runs were conducted at the temperature varied between 30 and $90^{\circ} \mathrm{C}$ with the $\mathrm{Al} / \mathrm{Co}$ ratio fixed at 2000 over the reaction time of $30 \mathrm{~min}$ (Table 3, entries 1-7); the dependence of the catalytic activity and the polyethylene molecular weight on the reaction temperature is plotted in Figure 3, which shows that the activity gradually increases with the temperature and achieves the highest value of $7.36 \times 10^{6} \mathrm{~g}$ of PE (mol of Co$)^{-1} \mathrm{~h}^{-1}$ at $60^{\circ} \mathrm{C}$ (Table 3, entry 4). The catalytic activity is still high at $70^{\circ} \mathrm{C}$, reaching $6.72 \times 10^{6} \mathrm{~g}$ of $\mathrm{PE}(\mathrm{mol} \text { of } \mathrm{Co})^{-1} \mathrm{~h}^{-1}$ and amounting to $4.10 \times 10^{6} \mathrm{~g}$ of PE (mol of $\left.\mathrm{Co}\right)^{-1} \mathrm{~h}^{-1}$ at $80^{\circ} \mathrm{C}$ (Table 3, entries 5, 6). Beyond that point, the activity sharply decreases to $1.40 \times 10^{6} \mathrm{~g}$ of PE (mol of Co) ${ }^{-1} \mathrm{~h}^{-1}$ at $90^{\circ} \mathrm{C}$ (Table 3, entry 7). These observations indicate thermally stable active sites and the decrease in catalytic activity can be ascribed to the lower solubility of ethylene or partial deactivation of active species at high temperature [9-12,36-46,57,61]. High melting point of the resultant polyethylene $\left(T_{\mathrm{m}}=130.7-135.6^{\circ} \mathrm{C}\right)$ indicates its linear structure; this fact is further confirmed by the high-temperature NMR $\left({ }^{1} \mathrm{H} /{ }^{13} \mathrm{C}\right)$ spectroscopy. Moreover, polyethylene molecular weight decreases from $4.50 \times 10^{5} \mathrm{~g} \mathrm{~mol}^{-1}$ to $0.20 \times 10^{5} \mathrm{~g} \mathrm{~mol}^{-1}$ when the polymerization temperature is raised from $30^{\circ} \mathrm{C}$ to $90^{\circ} \mathrm{C}$; this could be attributed either to the low solubility of ethylene monomer in toluene or the increased rates of chain transfer reactions at elevated temperature, or both (Figure 3) [36-46,57,61]. The effect of the Al/Co ratio ranging from 1500 to 3500 on the catalytic activity was studied at the optimized reaction temperature of $60^{\circ} \mathrm{C}$. The activity increases with the growing $\mathrm{Al} / \mathrm{Co}$ ratio, reaching $10.01 \times 10^{6} \mathrm{~g}$ of $\mathrm{PE}(\mathrm{mol} \mathrm{of} \mathrm{Co})^{-1} \mathrm{~h}^{-1}$ at $\mathrm{Al} / \mathrm{Co}=3000$ (Table 3, entry 11). Beyond that point the activity drops down to $7.68 \times 10^{6} \mathrm{~g}$ of $\mathrm{PE}(\mathrm{mol} \mathrm{of} \mathrm{Co})^{-1} \mathrm{~h}^{-1}$ at $\mathrm{Al} / \mathrm{Co}=3500$ (Table 3, entry 13). The molecular weight of polyethylene gradually increases from $0.40 \times 10^{5} \mathrm{~g} \mathrm{~mol}^{-1}$ to $0.52 \times 10^{5} \mathrm{~g} \mathrm{~mol}^{-1}$ when the $\mathrm{Al} / \mathrm{Co}$ ratio is raised from 1500 to 3000 (Table 3, entries 4, 8-11) and then sharply decreases to $0.38 \times 10^{5} \mathrm{~g} \mathrm{~mol}^{-1}$ (Table 3, entry 13)-see also Figure 4 . This decrease could be attributed to the chain migration and termination reactions occurring at higher concentration of the cocatalyst $[33,62]$. The polyethylene $T_{\mathrm{m}}$ values range from $132.1{ }^{\circ} \mathrm{C}$ to $132.9^{\circ} \mathrm{C}$ (Table 3, entries 4, 8-13). With the optimum values of the reaction temperature $\left(60^{\circ} \mathrm{C}\right)$ and the $\mathrm{Al} / \mathrm{Co}$ ratio (3000), the effect of reaction time ranging from 5 to $60 \mathrm{~min}$ on the polymerization process was explored (Table 3, entries 11, 14-17).

The catalytic activity is inversely related to the polymerization time, and the highest value of $21.60 \times 10^{6} \mathrm{~g}$ of PE (mol of $\left.\mathrm{Co}\right)^{-1} \mathrm{~h}^{-1}$ was found at $5 \mathrm{~min}$ run time, indicating a short induction time required to generate the active sites (Table 3, entry 14). With the prolonged reaction time the activity gradually decreases (Table 3 , entries 4 and 14-17) and the moderate value of $5.81 \times 10^{6} \mathrm{~g}$ of PE (mol of $\mathrm{Co})^{-1} \mathrm{~h}^{-1}$ was found even for $60 \mathrm{~min}$ (Table 3, entry 17), suggesting rather long lifetime of the active sites. The molecular weight of the obtained polyethylene increases constantly with reaction time. The product exhibits unimodal molecular weight distribution and the melting point in the range of $132.1-132.8^{\circ} \mathrm{C}$. The plot of activity and the molecular weight of polyethylene as a function of the 
reaction time is given in Figure 5. Similar dependencies have been observed for the related catalytic systems [36-46].

Table 3. Optimization of the polymerization conditions for the Co1/MAO system ${ }^{a}$.

\begin{tabular}{ccccccccc}
\hline Entry & $\mathbf{T}_{\mathbf{~}}{ }^{\mathbf{}} \mathbf{C}$ & $\mathbf{t}, \mathbf{m i n}$ & $\mathbf{A} \mathbf{l} / \mathbf{C o}$ & $\mathbf{P E}, \mathbf{g}$ & Activity $^{\boldsymbol{b}}$ & $\boldsymbol{M}_{\mathbf{w}}{ }^{\mathbf{c}}$ & $\boldsymbol{M}_{\mathbf{w}} / \boldsymbol{M}_{\mathbf{n}}{ }^{\mathbf{c}}$ & $\mathbf{T}_{\mathbf{m}}{ }^{\circ} \mathbf{C}^{\boldsymbol{d}}$ \\
\hline 1 & 30 & 30 & 2000 & 3.51 & 4.68 & 4.50 & 2.80 & 135.6 \\
2 & 40 & 30 & 2000 & 4.18 & 5.57 & 4.01 & 2.79 & 135.6 \\
3 & 50 & 30 & 2000 & 4.82 & 6.43 & 3.05 & 3.61 & 135.5 \\
4 & 60 & 30 & 2000 & 5.52 & 7.36 & 0.41 & 3.16 & 134.2 \\
5 & 70 & 30 & 2000 & 5.04 & 6.72 & 0.30 & 2.58 & 131.8 \\
6 & 80 & 30 & 2000 & 3.07 & 4.09 & 0.23 & 3.60 & 131.5 \\
7 & 90 & 30 & 2000 & 1.04 & 1.39 & 0.20 & 5.18 & 130.7 \\
8 & 60 & 30 & 1500 & 1.93 & 1.85 & 0.40 & 2.84 & 132.9 \\
9 & 60 & 30 & 2500 & 5.83 & 7.77 & 0.43 & 3.22 & 132.7 \\
10 & 60 & 30 & 2750 & 6.81 & 9.08 & 0.44 & 2.86 & 132.7 \\
11 & 60 & 30 & 3000 & 7.51 & 10.0 & 0.52 & 2.45 & 132.6 \\
12 & 60 & 30 & 3250 & 7.04 & 9.39 & 0.46 & 1.98 & 132.9 \\
13 & 60 & 30 & 3500 & 5.76 & 7.68 & 0.38 & 2.50 & 132.6 \\
14 & 60 & 5 & 3000 & 2.07 & 21.6 & 0.30 & 2.84 & 132.1 \\
15 & 60 & 15 & 3000 & 4.25 & 11.3 & 0.50 & 3.45 & 133.1 \\
16 & 60 & 45 & 3000 & 7.91 & 7.03 & 0.53 & 2.31 & 133.3 \\
17 & 60 & 60 & 3000 & 8.72 & 5.81 & 0.60 & 2.88 & 132.8 \\
$18^{e}$ & 60 & 30 & 3000 & 3.98 & 5.10 & 0.24 & 2.91 & 131.4 \\
$19^{f}$ & 60 & 30 & 3000 & 0.64 & 0.85 & 0.02 & 1.82 & 123.1 \\
\hline
\end{tabular}

a General conditions: $1.5 \mu \mathrm{mol}$ of $\mathrm{Co1}, 100 \mathrm{~mL}$ toluene, $10 \mathrm{~atm} \mathrm{C}_{2} \mathrm{H}_{4}$, unless indicated otherwise. ${ }^{b} 10^{6} \mathrm{~g}$ of PE $\mathrm{mol}^{-1}(\mathrm{Co}) \mathrm{h}^{-1} .{ }^{\mathrm{c}} 10^{5} \mathrm{~g} \mathrm{~mol}^{-1}$, determined by GPC. ${ }^{d}$ Determined by DSC. ${ }^{e} 5 \mathrm{~atm} \mathrm{C}_{2} \mathrm{H}_{4} .{ }^{f} 1 \mathrm{~atm} \mathrm{C}_{2} \mathrm{H}_{4}$.
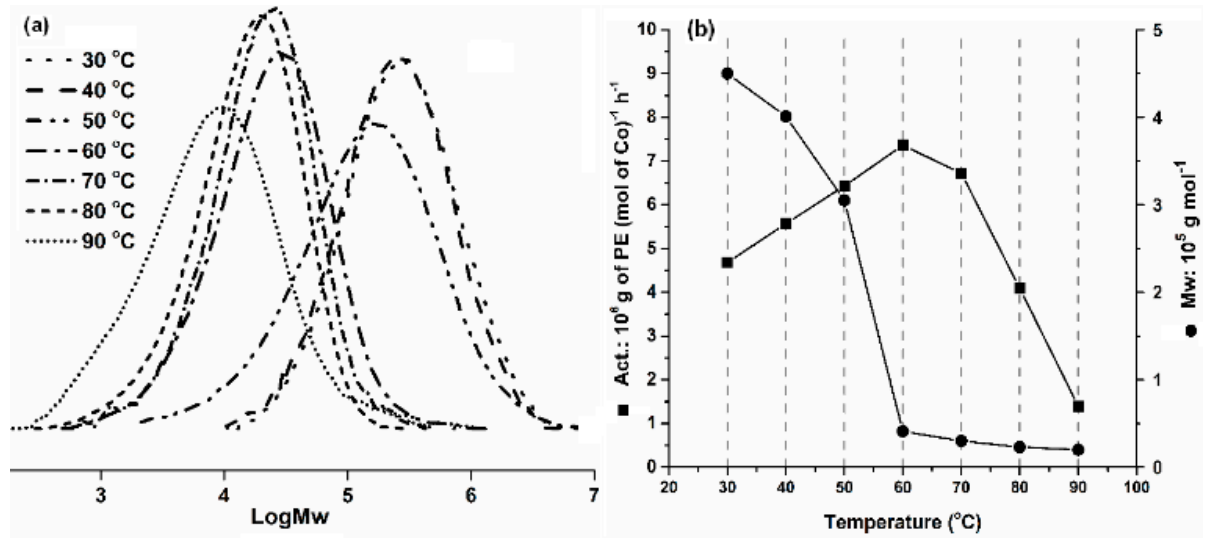

Figure 3. GPC curves of the obtained polyethylene (a); activity and $M_{\mathrm{W}}$ as a function of reaction temperature (b) for the Co1/MAO system (Table 3, entries 1-7).
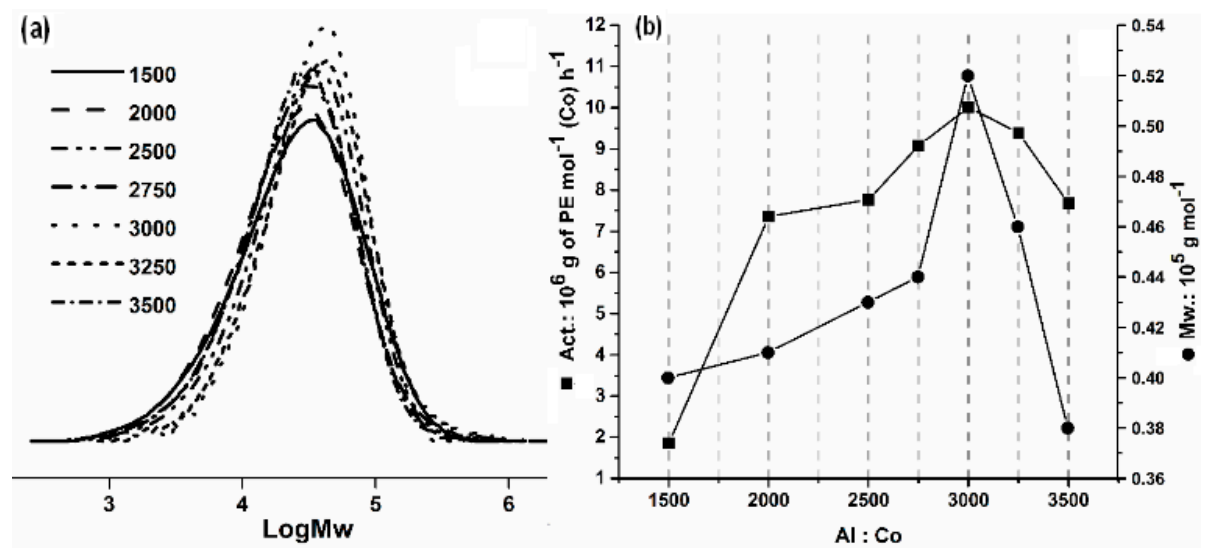

Figure 4. GPC curves of the obtained polyethylene (a); activity and $M_{\mathrm{W}}$ as a function of the $\mathrm{Al} / \mathrm{Co}$ ratio (b) for the Co1/MAO system (Table 3, entries 4 and 8-13). 

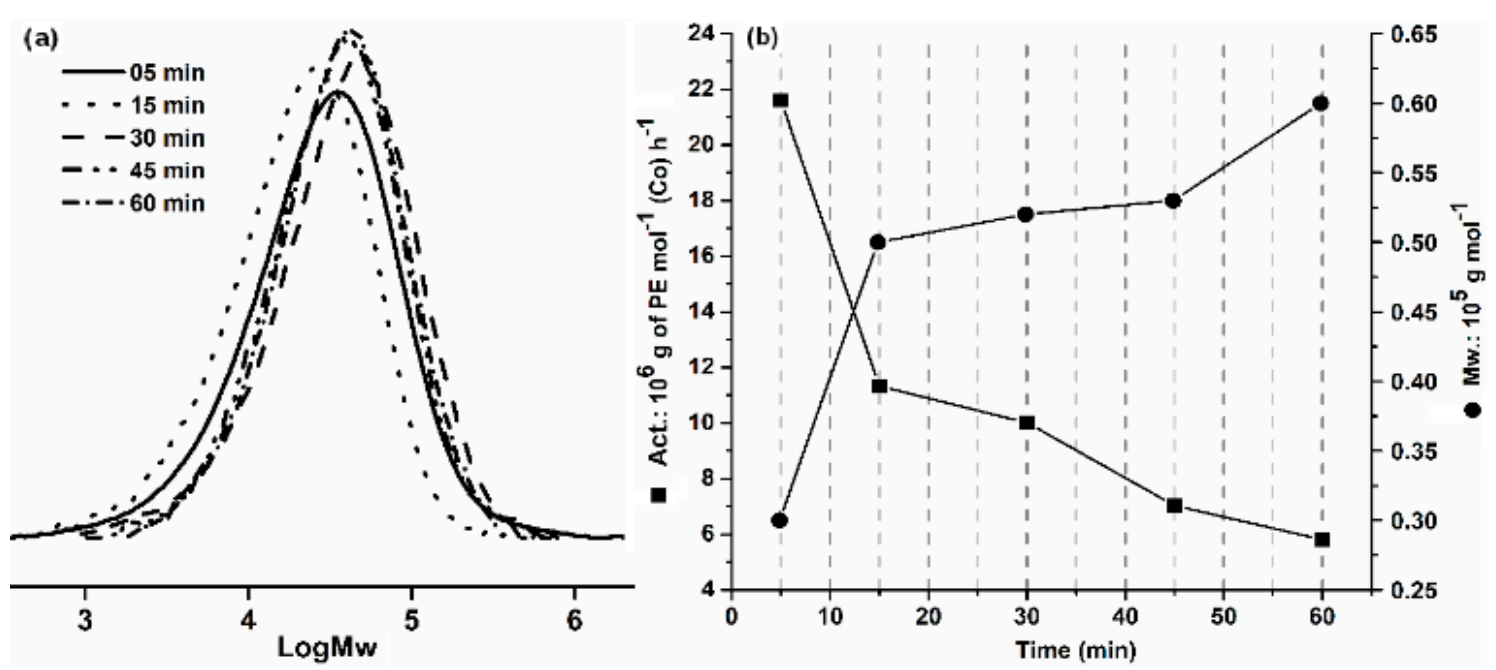

Figure 5. GPC curves of the obtained polyethylene (a); activity and $M_{\mathrm{w}}$ as a function of reaction time (b) for the Co1/MAO system (Table 3, entries 11 and 14-17).

The performance of the remaining cobalt precatalysts (Co2-Co5) in ethylene polymerization was investigated at the optimum reaction conditions established for the Co1/MAO system, i.e., the reaction temperature of $60^{\circ} \mathrm{C}$, the $\mathrm{Al} / \mathrm{Co}$ ratio of 3000 , ethylene pressure of $10 \mathrm{~atm}$ and the run time of $30 \mathrm{~min}$-see Table 4, entries $1-5$. Steric effects have impact on the overall catalytic activity, which decreases in the following order: $\mathrm{Co} 1>\mathrm{Co} 4>\mathrm{Co} 5>\mathrm{Co} 2>\mathrm{Co} 3$; thus the highest activity of $10.01 \times 10^{6} \mathrm{~g}$ of PE (mol of $\mathrm{Co})^{-1} \mathrm{~h}^{-1}$ is attained by the Co1 precatalyst with the least bulky substituent $\mathrm{R}^{1}$; likewise Co3 bearing relatively bulky $\mathrm{R}^{1}$ displays the lowest activity of $7.49 \times 10^{6} \mathrm{~g}$ of $\mathrm{PE}(\mathrm{mol} \mathrm{of} \mathrm{Co})^{-1} \mathrm{~h}^{-1}$. The values of activity and the polyethylene molecular weight for Co1-Co5 are given in Figure 6. The advantageous effect of bulky $\mathrm{R}^{1}$ substituent on the polyethylene molecular weight is clearly seen for Co3 (Table 4, entry 3), where the polymer of relatively high molecular weight is generated (Table 4, entry 3). This indicates that bulky substituents protect the active sites and suppress the chain transfer. Similar observations were reported in the literature $[33,36,38,39,42,45]$. The polyethylene obtained using the Co1-Co5 precatalysts displays high melting point $\left(T_{m}\right)$ of $132.3-135.7^{\circ} \mathrm{C}$ (Table 4, entries 1-5); this finding is also in good agreement with the previous reports on bis(imino)pyridine catalysts [36-46]. In order to examine the effect of ethylene pressure on the catalytic activity and the molecular weight of the product, further polymerization tests were run at the optimized reaction conditions $\left(\mathrm{T}=60^{\circ} \mathrm{C}\right.$, $\mathrm{Al} / \mathrm{Co}=3000$ and $\mathrm{t}=30 \mathrm{~min}$ ) at 5 and $1 \mathrm{~atm}$ (Table 3, entries 18 and 19). The results indicating strong influence of pressure on both quantities are shown in Figure 7. In the case of polyethylene, unimodal molecular weight distribution and the melting points $\left(T_{m}\right)$ of 131.4 and $123.1^{\circ} \mathrm{C}$ were attained for $\mathrm{p}=5$ and $\mathrm{p}=1 \mathrm{~atm}$, respectively.

Table 4. Ethylene polymerization with (Co1-Co5)/MAO under the optimized conditions ${ }^{a}$.

\begin{tabular}{ccccccc}
\hline Entry & Precatalyst & PE, $\mathbf{g}$ & Activity $^{\boldsymbol{b}}$ & $\boldsymbol{M}_{\mathbf{w}}{ }^{\mathbf{c}}$ & $\boldsymbol{M}_{\mathbf{w}} / \boldsymbol{M}_{\mathbf{n}}{ }^{\mathbf{c}}$ & $\boldsymbol{T}_{m}{ }^{\circ} \mathbf{C}^{d}$ \\
\hline 1 & Co1 & 7.51 & 10.0 & 0.52 & 2.45 & 132.6 \\
2 & Co2 & 6.23 & 8.31 & 0.53 & 2.42 & 133.7 \\
3 & Co3 & 5.62 & 7.49 & 1.14 & 2.84 & 135.7 \\
4 & Co4 & 7.06 & 9.41 & 0.35 & 2.12 & 132.3 \\
5 & Co5 & 6.70 & 8.93 & 0.61 & 2.94 & 132.9 \\
\hline
\end{tabular}

${ }^{a}$ General conditions: $1.5 \mu \mathrm{mol}$ of precatalyst, $100 \mathrm{~mL}$ toluene, $10 \mathrm{~atm} \mathrm{C}_{2} \mathrm{H}_{4}, 60{ }^{\circ} \mathrm{C}, 30 \mathrm{~min}, \mathrm{Al} / \mathrm{Co}$ ratio of $3000 .{ }^{b} 10^{6}$ $\mathrm{g} \mathrm{PE} \mathrm{mol}{ }^{-1}(\mathrm{Co}) \mathrm{h}^{-1} \cdot{ }^{c} 10^{5} \mathrm{~g} \mathrm{~mol}^{-1}$, determined by GPC. ${ }^{d}$ Determined by DSC. 


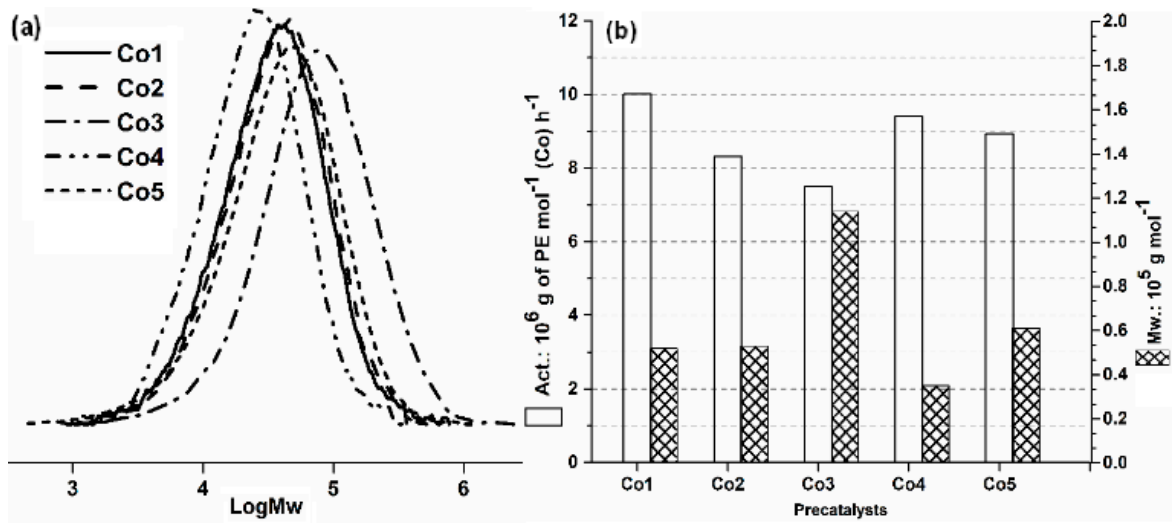

Figure 6. GPC curves of the obtained polyethylene (a); activity and $M_{\mathrm{W}}$ for different precatalysts at the optimized reaction conditions (b) —see Table 4, entries 1-5.
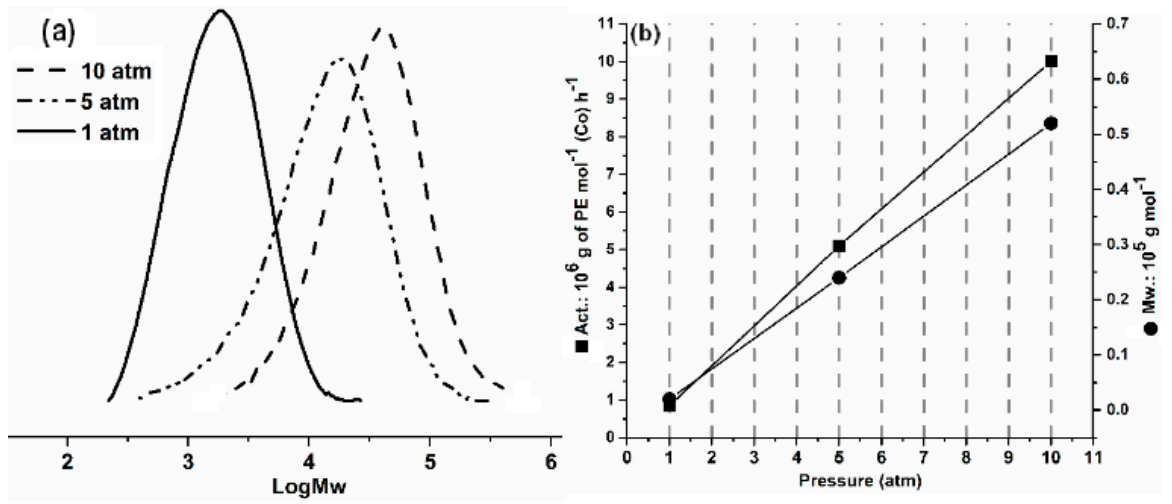

Figure 7. GPC curves of the obtained polyethylene (a); activity and $M_{\mathrm{W}}$ as a function of ethylene pressure (b) for the Co1/MAO system at the optimized reaction conditions (Table 3, entries 11, 18 and 19).

\subsubsection{Ethylene Polymerization with (Co1-Co5)/MMAO}

The data for ethylene polymerization catalyzed with the Co1/MMAO system are shown in Table 5 in a similar manner as in the case of the Co1/MAO system. Typical ethylene polymerization runs were performed in toluene at the $\mathrm{Al} / \mathrm{Co}$ ratio fixed at 2000, under $10 \mathrm{~atm}$ ethylene pressure and over reaction time of $30 \mathrm{~min}$. Initially, the reaction temperature was varied from 30 to $90{ }^{\circ} \mathrm{C}$ (Table 5, entries 1-7 and Figure S6), and the gradual increase in the catalytic activity reaching the maximum of $6.28 \times 10^{6} \mathrm{~g}$ of PE (mol of $\left.\mathrm{Co}\right)^{-1} \mathrm{~h}^{-1}$ at $50^{\circ} \mathrm{C}$ was observed (Table 5 , entry 3$)$. Beyond that point the activity drops, which can be attributed to the partial deactivation of active species or lower solubility of ethylene at elevated temperature [36-46,57,61]; but the relatively high value of $2.99 \times 10^{6} \mathrm{~g}$ of PE $(\mathrm{mol} \text { of } \mathrm{Co})^{-1} \mathrm{~h}^{-1}$ is maintained at $80^{\circ} \mathrm{C}$ and $1.89 \times 10^{6} \mathrm{~g}$ of $\mathrm{PE}(\mathrm{mol} \mathrm{of} \mathrm{Co})^{-1} \mathrm{~h}^{-1}$ is still attainable even at $90^{\circ} \mathrm{C}$ (Table 5, entry 7). Again, unprecedented thermal stability was recorded for the Co1/MMAO system, which-however - does not surpass the Co1/MAO catalyst described in the previous section. As a result of increased polymerization temperature, the molecular weight of polyethylene decreases from 3.80 to $0.25 \times 10^{5} \mathrm{~g} \mathrm{~mol}^{-1}$ (Table 5, entries 1-7). The impact of temperature on the activity and molecular weight shown in Figure S6 indicates unimodal molecular weight distributions. In the next step, the $\mathrm{Al} / \mathrm{Co}$ molar ratio was varied from 1000 to 3000 and the polymerization was carried out at the optimized temperature of $50^{\circ} \mathrm{C}$ (Table 5, entries 3 and 8-13). The catalytic activity first increases, reaching the maximum value of $7.89 \times 10^{6} \mathrm{~g}$ of $\mathrm{PE}(\mathrm{mol} \mathrm{of} \mathrm{Co})^{-1} \mathrm{~h}^{-1}$ at the $\mathrm{Al} / \mathrm{Co}$ ratio of 1500 (Table 5, entry 10), and then decreases (Table 5, entries 11-13; see also Figure S7).

The deactivation observed at higher $\mathrm{Al} / \mathrm{Co}$ ratios may be ascribed to more frequent events of chain transfer from cobalt to aluminium $[33,62,63]$. Then, the stability of active sites was studied under optimized reaction temperature of $50^{\circ} \mathrm{C}$ and the $\mathrm{Al} / \mathrm{Co}$ molar ratio of 1500 for the reaction time from 5 
to $60 \mathrm{~min}$ (Table 5, entries 10,14-17). The catalytic activity is again inversely related to the reaction time-the highest value of $28.80 \times 10^{6} \mathrm{~g}$ of PE (mol of Co) ${ }^{-1} \mathrm{~h}^{-1}$ was found for the 5 min run time, which indicates a short induction time necessary to generate the active sites (Table 5, entry 14). After that, the catalytic activity steadily decreases on prolonging the polymerization time (Table 5, entries 15-17) and the lowest activity of $5.76 \times 10^{6} \mathrm{~g}$ of PE (mol of $\left.\mathrm{Co}\right)^{-1} \mathrm{~h}^{-1}$ is found for the polymerization time of $60 \mathrm{~min}$ (Table 5, entry 17). These observations are similar to those made for the Co1/MAO system and agree with the previous reports on bis(imino)pyridine catalysts [36-46]. The catalyst still retains remarkable activity after $60 \mathrm{~min}$, which suggests relatively long lifetime of the active sites. Moreover, the molecular weight of the obtained polyethylene steadily increases with the reaction time. The high melting point $\left(T_{m}\right)$ of $135.3-135.6{ }^{\circ} \mathrm{C}$ and unimodal molecular weight distributions are the typical features of the obtained polyethylene (Figure S8).

Table 5. Optimization of the polymerization conditions for the Co1/MMAO system ${ }^{a}$.

\begin{tabular}{ccccccccc}
\hline Entry & $\mathbf{T}^{\circ}{ }^{\circ} \mathbf{C}$ & $\mathbf{T}, \mathbf{m i n}$ & $\mathbf{A} \mathbf{l} / \mathbf{C o}$ & $\mathbf{P E}, \mathbf{g}$ & Activity & $\boldsymbol{M}_{\mathbf{w}}{ }^{\boldsymbol{c}}$ & $\boldsymbol{M}_{\mathbf{w}} / \boldsymbol{M}_{\boldsymbol{n}}{ }^{c}$ & $\boldsymbol{T}_{\boldsymbol{m}}{ }^{\circ} \mathbf{C}^{\boldsymbol{d}}$ \\
\hline 1 & 30 & 30 & 2000 & 3.91 & 5.21 & 3.80 & 3.70 & 135.8 \\
2 & 40 & 30 & 2000 & 4.34 & 5.79 & 2.51 & 2.53 & 136.2 \\
3 & 50 & 30 & 2000 & 4.71 & 6.28 & 1.98 & 2.65 & 135.8 \\
4 & 60 & 30 & 2000 & 3.09 & 4.12 & 0.73 & 3.65 & 132.9 \\
5 & 70 & 30 & 2000 & 2.80 & 3.73 & 0.36 & 3.02 & 134.6 \\
6 & 80 & 30 & 2000 & 2.24 & 2.99 & 0.30 & 3.08 & 131.6 \\
7 & 90 & 30 & 2000 & 1.42 & 1.89 & 0.25 & 2.91 & 131.3 \\
8 & 50 & 30 & 1000 & 3.48 & 4.64 & 0.97 & 3.68 & 135.2 \\
9 & 50 & 30 & 1250 & 5.24 & 6.99 & 2.02 & 3.43 & 135.4 \\
10 & 50 & 30 & 1500 & 5.92 & 7.89 & 2.16 & 3.92 & 135.3 \\
11 & 50 & 30 & 1750 & 5.03 & 6.71 & 2.38 & 3.64 & 135.7 \\
12 & 50 & 30 & 2500 & 4.01 & 5.35 & 1.85 & 3.35 & 135.7 \\
13 & 50 & 30 & 3000 & 3.76 & 5.01 & 1.61 & 2.12 & 134.9 \\
14 & 50 & 5 & 1500 & 3.60 & 28.8 & 1.69 & 2.70 & 135.6 \\
15 & 50 & 15 & 1500 & 4.65 & 12.4 & 1.75 & 2.83 & 135.5 \\
16 & 50 & 45 & 1500 & 6.73 & 5.98 & 2.20 & 2.65 & 135.4 \\
17 & 50 & 60 & 1500 & 8.64 & 5.76 & 2.25 & 3.89 & 135.3 \\
$18^{e}$ & 50 & 30 & 1500 & 2.76 & 3.68 & 0.84 & 3.78 & 133.7 \\
$19^{f}$ & 50 & 30 & 1500 & 0.35 & 0.47 & 0.08 & 2.36 & 128.7 \\
\hline
\end{tabular}

${ }^{a}$ General conditions: $1.5 \mu \mathrm{mol}$ of Co1, $100 \mathrm{~mL}$ toluene, $10 \mathrm{~atm} \mathrm{C}_{2} \mathrm{H}_{4} \cdot{ }^{b} 10^{6} \mathrm{~g}$ of PE mol${ }^{-1}(\mathrm{Co}) \mathrm{h}^{-1} \cdot{ }^{c} 10^{5} \mathrm{~g} \mathrm{~mol}{ }^{-1}$, determined by GPC. ${ }^{d}$ Determined by DSC. ${ }^{e} 5 \mathrm{~atm} \mathrm{C}_{2} \mathrm{H}_{4} .{ }^{f} 1 \mathrm{~atm} \mathrm{C}_{2} \mathrm{H}_{4}$.

The catalytic performance of the remaining precatalysts Co2-Co5 was studied in the optimized polymerization conditions determined for the Co1/MMAO system $\left(\mathrm{Al} / \mathrm{Co}=1500, \mathrm{~T}=50{ }^{\circ} \mathrm{C}, \mathrm{p}=10\right.$ atm and $t=30 \mathrm{~min}$ ); see Table 6 , entries $1-5$. The Co1 precatalyst with the lowest steric hindrance around the active site exhibits the highest activity of $7.89 \times 10^{6} \mathrm{~g}$ of PE (mol of Co $)^{-1} \mathrm{~h}^{-1}$ (Table 6 , entry 1) and the overall catalytic activity decreases in the following order: Co1 > Co4 > Co2 > Co5 > Co3, which-by analogy to other cobalt precatalysts $[36,38,39,42,45]$-indicates the pronounced effect of $\mathrm{R}^{1}$ on the activity (see Figure S9). It must be mentioned that the precatalysts activated with MMAO generate polyethylene of much higher molecular weight (Table 6, entry 3), compared with the systems containing MAO (Table 4, entry 3) [33,36]. Ethylene pressure has also marked effect on the catalytic activity and the polyethylene molecular weight (Figure S10); the trends are similar to those observed for the Co1/MAO system.

Table 6. Ethylene polymerization with the (Co1-Co5)/MMAO at the optimized conditions ${ }^{a}$.

\begin{tabular}{ccccccc}
\hline Entry & Precatalyst & PE, $\mathbf{g}$ & Activity $^{b}$ & $\boldsymbol{M}_{\mathbf{w}}{ }^{\mathbf{c}}$ & $\boldsymbol{M}_{\mathbf{w}} / \boldsymbol{M}_{\mathbf{n}}{ }^{\mathbf{c}}$ & $\boldsymbol{T}_{\mathbf{m}},{ }^{\circ} \mathbf{C}^{\mathbf{d}}$ \\
\hline 1 & Co1 & 5.92 & 7.89 & 2.38 & 3.92 & 135.3 \\
2 & $\mathbf{C o 2}$ & 5.53 & 7.37 & 5.78 & 6.62 & 135.7 \\
3 & Co3 & 5.04 & 6.72 & 6.46 & 3.17 & 136.8 \\
4 & $\mathbf{C o 4}$ & 5.74 & 7.65 & 3.70 & 5.79 & 136.8 \\
5 & Co5 & 5.42 & 7.23 & 3.92 & 3.19 & 136.7
\end{tabular}

${ }^{a}$ General conditions: $1.5 \mu \mathrm{mol}$ of precatalyst, $100 \mathrm{~mL}$ toluene, $10 \mathrm{~atm} \mathrm{C}_{2} \mathrm{H}_{4}, 50{ }^{\circ} \mathrm{C}, 30 \mathrm{~min}, \mathrm{Al} / \mathrm{Co}$ ratio of $1500 .{ }^{b} 10^{6}$ $\mathrm{g} \mathrm{PE} \mathrm{mol}{ }^{-1}(\mathrm{Co}) \mathrm{h}^{-1} .{ }^{c} 10^{5} \mathrm{~g} \mathrm{~mol}^{-1}$, determined by GPC. ${ }^{d}$ Determined by DSC. 


\subsection{Polyethylene Microstructural Properties}

Relatively high value of melting point $\left(132.3-135.7^{\circ} \mathrm{C}\right)$ for the majority of polyethylene samples obtained at different reaction conditions indicates highly linear macromolecules. More detailed investigation of the product microstructure was carried out by means of high-temperature ${ }^{1} \mathrm{H}$ - and ${ }^{13} \mathrm{C}-\mathrm{NMR}$ spectroscopy for the representative sample obtained with $\mathrm{Co1} / \mathrm{MAO}$ at $60{ }^{\circ} \mathrm{C}$ (Table 3, entry 11). The spectra were recorded in 1,1,2,2-teterachloroethane- $d$ at $100^{\circ} \mathrm{C}$ and interpreted according to literature method $[38,39,45,64-66]$.

The ${ }^{1} \mathrm{H}-\mathrm{NMR}$ spectrum (Figure 8 ) reveals the coexistence of polyethylene bearing both saturated and unsaturated end groups. However, the exact ratio of both polymer types is unclear due to overlapping peaks. Vinyl end groups $\left(-\mathrm{CH}=\mathrm{CH}_{2}\right)$ were identified as two multiplets around 5.86 and $5.03 \mathrm{ppm}$ with the relative peak area of 1 and 2. High intensity singlet at around 1.38 ppm corresponding to the protons of the $-\left(\mathrm{CH}_{2}\right)_{n}$ - mers and another signal at $2.13 \mathrm{ppm}$ due to the protons adjacent to the vinyl group $\left(\mathrm{H}_{\mathrm{c}}\right)$ were observed. The signal of the methyl group $\left(\mathrm{H}_{\mathrm{g}}\right)$ at $0.99 \mathrm{ppm}$ overlaps with the $-\left(\mathrm{CH}_{2}\right)_{\mathrm{n}}$ - band; therefore the exact ratio of unsaturated to saturated end groups cannot be determined. The NMR spectra suggest a highly linear structure of both saturated and unsaturated polyethylene. The presence of the vinyl end group was further confirmed by the ${ }^{13} \mathrm{C}-\mathrm{NMR}$ spectrum (Figure 9), in which two distinct peaks belonging to the vinyl carbon atoms located at the end of the polymer chain $\left(C_{a}\right.$ and $\left.C_{b}\right)$ were detected at 114.39 and $139.39 \mathrm{ppm}$, together with the peak corresponding to the adjacent carbon atom $\left(\mathrm{C}_{\mathrm{c}}\right)$ at $33.93 \mathrm{ppm}$. The signal of the $-\left(\mathrm{CH}_{2}\right)_{\mathrm{n}}-$ mers was recorded at $30.00 \mathrm{ppm}$. The carbon atoms of the methyl group at the saturated end of the macromolecule were observed at $14.22 \mathrm{ppm}\left(\mathrm{C}_{\mathrm{g}}\right)$, along with the carbon atoms located at the close vicinity $\left(C_{d}, C_{e}\right.$, and $\left.C_{f}\right)$ at 32.24, 22.92 and 18.33 ppm, respectively $[38,39,45,64-66]$.

The high melting point of another set of samples corresponding to the polyethylene obtained with the Co1/MMAO system (131.3-136.2 ${ }^{\circ} \mathrm{C}$ ) suggests highly linear saturated polymer (Table 5, entry 1-7). This was further confirmed by the high-temperature ${ }^{1} \mathrm{H}-1{ }^{13} \mathrm{C}-\mathrm{NMR}$ spectra of the selected representative sample obtained at the conditions defined in Table 5 , entry 10 . The signals corresponding to the $-\left(\mathrm{CH}_{2}\right)_{\mathrm{n}}-$ mers $[38,39,45,64-66]$ observed in both spectra (Figs. S11 and S12) reveal highly linear and saturated polyethylene.

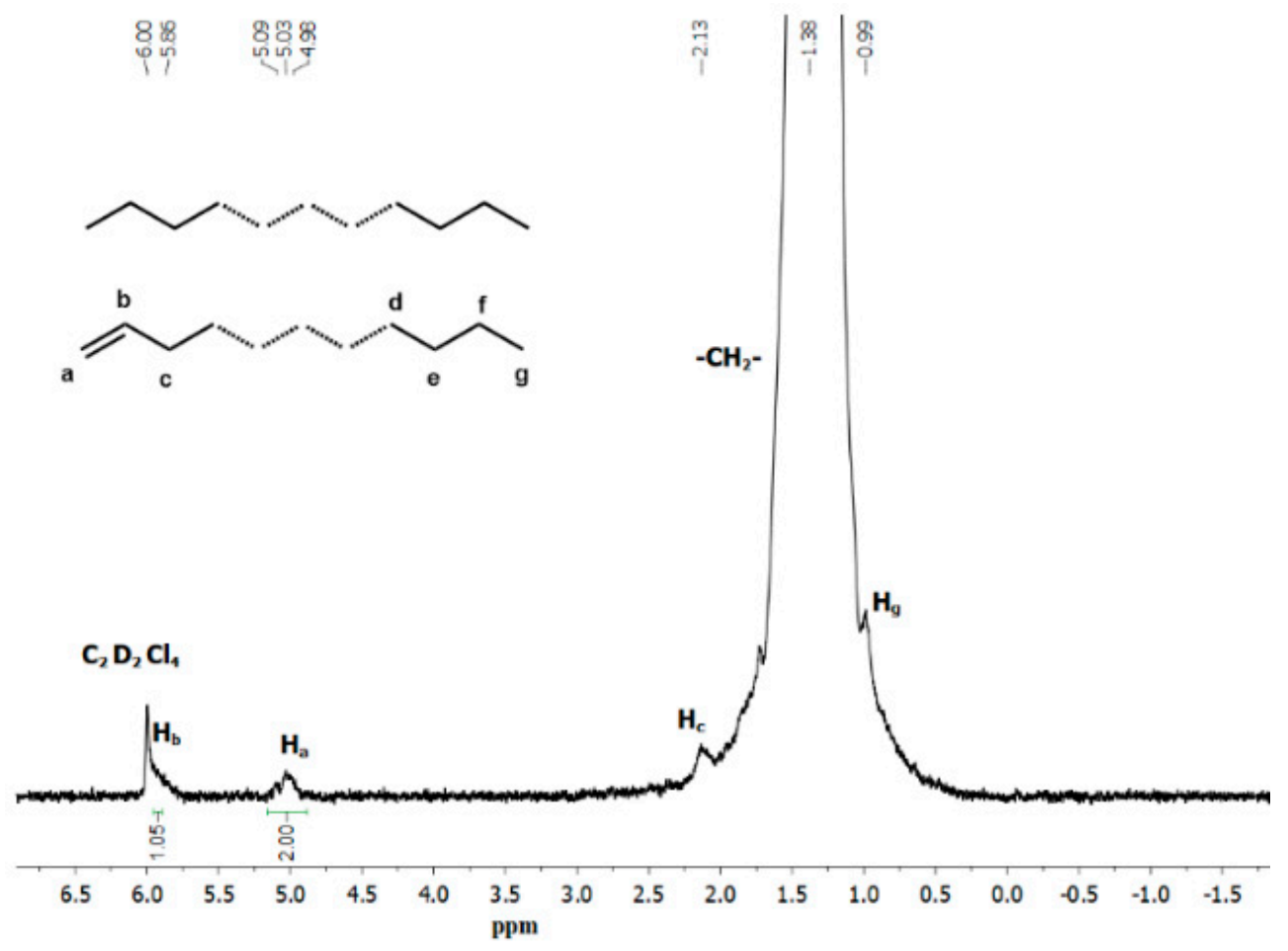

Figure 8. ${ }^{1} \mathrm{H}-\mathrm{NMR}$ spectrum of the polyethylene obtained with Co1/MAO (Table 3, entry 11). 


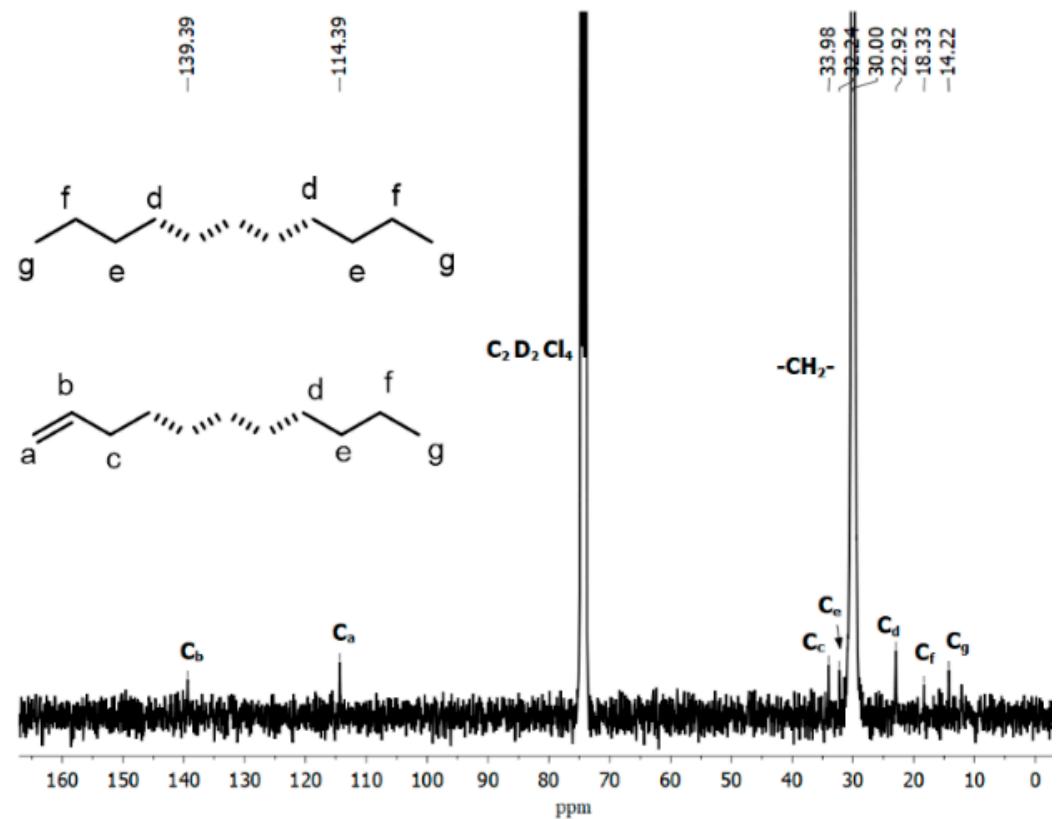

Figure 9. ${ }^{13} \mathrm{C}-\mathrm{NMR}$ spectrum of the polyethylene obtained with Co1/MAO (Table 3, entry 11)

\subsection{Comparison of the Current Precatalyst with Systems Reported Before}

The comparison of the precatalyst investigated in this work with the previously reported cobalt systems $[39,42,45]$ shown in Figure 10 reveals several interesting trends. The unprecedented thermal stability observed for the current system highlights the potential of the dibenzocycloheptyl substituent introduced in this work. Comparing with the catalysts reported before, polyethylene of the highest molecular weight was obtained due to the bulkiness that prevents chain transfer by protecting the active sites; this finding is consistent with the literature [33,36]. Interestingly, the catalytic activity is not impaired significantly and the current system is able to outperform several precatalysts with the benzhydryl substituents attached to the aryl rings [39,42].

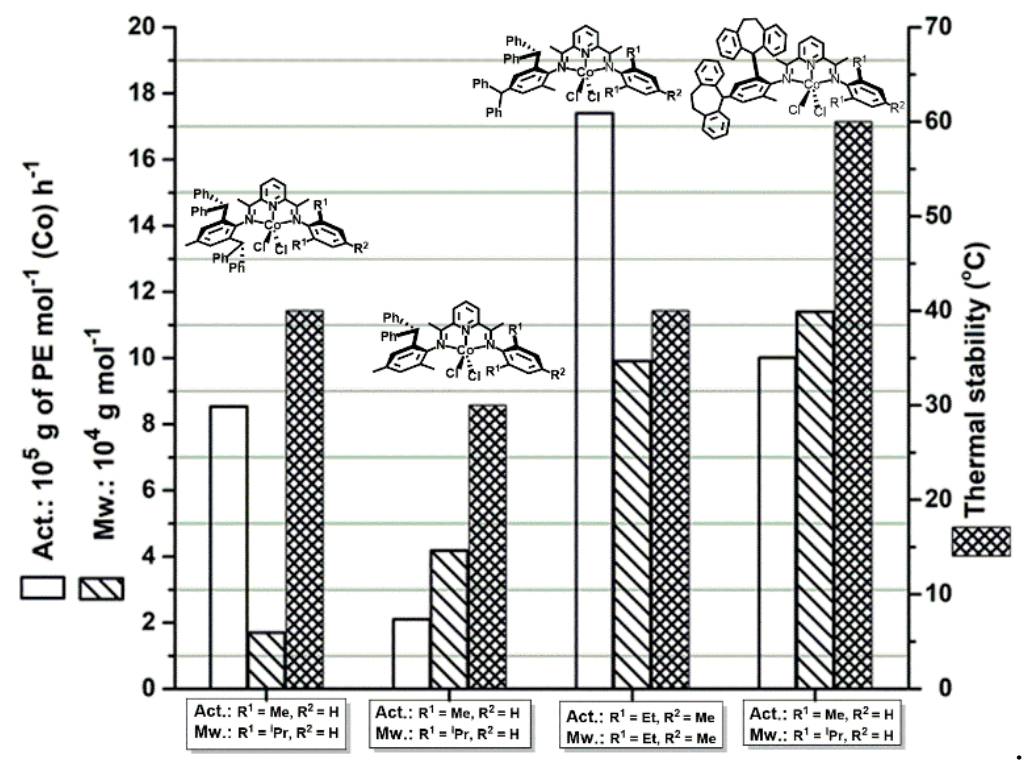

Figure 10. Comparison of the catalytic activity, polyethylene molecular weight and thermal stability of the selected precatalysts bearing benzhydryl groups with the current system at the optimized conditions with MAO or MMAO as cocatalysts and 10 atm of $\mathrm{C}_{2} \mathrm{H}_{4}$. 


\section{Materials and Methods}

\subsection{General Information}

All manipulations involving air or moisture sensitive compounds were carried out using standard Schlenk techniques under inert nitrogen atmosphere. The solvents were distilled under a nitrogen atmosphere prior to use. Methylaluminoxane (MAO, $1.46 \mathrm{M}$ in toluene) and modified methylaluminoxane (MMAO, 1.93 M in $n$-heptane) were purchased from Albemarle Corp. (Nanjing, China). High-purity ethylene was purchased from Beijing Yanshan Petrochemical Co. (Beijing, China) and used as received. All other reagents were purchased from Aldrich (Beijing, China), Acros (Beijing, China) or Beijing Chemicals (Beijing, China). 2,4-bis(Dibenzocycloheptyl)-6-methylaniline was prepared using the procedure reported in the literature [51-55]. The ${ }^{1} \mathrm{H}$ - and ${ }^{13} \mathrm{C}-\mathrm{NMR}$ spectra of the free ligands and complexes were recorded on a DMX $400 \mathrm{MHz}$ instrument (Bruker, Karlsruhe, Germany) at ambient temperature with TMS as an internal standard. The FT-IR spectra were recorded on a System 2000 FT-IR spectrometer (Perkin Elmer, Shanghai, China) and elemental analyses were determined using a Flash EA 1112 microanalyzer (Thermo Electron SPA, Beijing, China). The molecular weight $\left(M_{\mathrm{W}}\right)$ and molecular weight distribution $\left(M_{\mathrm{w}} / M_{\mathrm{n}}\right)$ of the polyethylene were determined using a PL-GPC220 instrument (Beijing, China) at $150{ }^{\circ} \mathrm{C}$ using 1,2,4-trichlorobenzene as a solvent. The polyethylene melting point was measured with differential scanning calorimetry (DSC, Q2000, TA Instruments, Beijing, China) under nitrogen atmosphere. A typical polyethylene sample of approximately $5.0 \mathrm{mg}$ was heated up to $160^{\circ} \mathrm{C}$ at a heating rate of $20^{\circ} \mathrm{C}$ per minute and kept for $3 \mathrm{~min}$ at this temperature to remove its thermal history; then it was cooled to $-20^{\circ} \mathrm{C}$ at the rate of $20{ }^{\circ} \mathrm{C}$ per minute. For the ${ }^{13} \mathrm{C}-\mathrm{NMR}$ spectra of polyethylene, a weighed sample (90-100 mg) was mixed with 1,1,2,2-tetrachloroethane- $d_{2}(2 \mathrm{~mL})$ in a $5 \mathrm{~mm}$ standard glass tube; TMS was applied as an internal standard. Inverse-gated ${ }^{13} \mathrm{C}$ spectra were recorded at $100{ }^{\circ} \mathrm{C}$ on a Bruker DMX 300 spectrometer at $75.47 \mathrm{MHz}$ with the number of scans from 3934 to 3966. Operating conditions used: spectral width $17,985.6 \mathrm{kHz}$; acquisition time $1.8 \mathrm{~s}$; relaxation delay $2.0 \mathrm{~s}$ and pulse width $15.5 \mu \mathrm{s}$.

\subsection{Synthesis of 2-acetyl-6-\{1-(2,4-bis(dibenzocycloheptyl)-6-methylphenylimino)ethyl\}pyridine}

A mixture of 2,6-diacetylpyridine $(2.13 \mathrm{~g}, 13.10 \mathrm{mmol})$ and 2,4-bis(dibenzocycloheptyl)-6- methylaniline $(6.42 \mathrm{~g}, 13.10 \mathrm{mmol})$ was added into toluene $(100 \mathrm{~mL})$ along with a catalytic amount of $p$-toluenesulfonic acid (15\%). The mixture was refluxed for $10 \mathrm{~h}$ and upon completion of reaction (checked with TLC) the volatiles were evaporated at reduced pressure. The residue was purified by column chromatography (basic alumina); elution with petroleum ether/ethyl acetate (25:2) afforded a yellow powder (3.1 $\mathrm{g}$, 37\%). Mp: 201-203 ${ }^{\circ} \mathrm{C}$. FT-IR ( $\left.\mathrm{KBr} \mathrm{cm}^{-1}\right)$ : $3050(\mathrm{w}), 3061(\mathrm{w}), 3013(\mathrm{w}), 2925(\mathrm{w}), 2831(\mathrm{w}), 2835(\mathrm{w})$, $1703(v(C=O), s), 1630(v(C=N), m), 1609(w), 1555(w), 1519(w), 1489(\mathrm{~m}), 1454(\mathrm{w}), 1435(\mathrm{w}), 1354(\mathrm{~s})$, $1308(\mathrm{~m}), 1238(\mathrm{~m}), 1160(\mathrm{w}), 1124(\mathrm{w}), 1098(\mathrm{w}), 1071(\mathrm{w}), 1047(\mathrm{w}), 1019(\mathrm{w}), 995(\mathrm{w}), 947(\mathrm{w}), 920(\mathrm{w})$, $882(\mathrm{w}), 842(\mathrm{w}), 812(\mathrm{~m}), 792(\mathrm{w}), 758(\mathrm{~s}), 738(\mathrm{~m}), 705(\mathrm{~m}), 677(\mathrm{w}) .{ }^{1} \mathrm{H}-\mathrm{NMR}\left(\mathrm{CDCl}_{3}, \mathrm{TMS}\right): \delta 8.60$ $(\mathrm{d}, J=8.04 \mathrm{~Hz}, 1 \mathrm{H}, \mathrm{Py}-\mathrm{H}), 8.13(\mathrm{~d}, J=7.60 \mathrm{~Hz}, 1 \mathrm{H}, \mathrm{Py}-\mathrm{H}), 7.97(\mathrm{t}, J=7.80 \mathrm{~Hz}, 1 \mathrm{H}, \mathrm{Py}-\mathrm{H}), 7.20-6.77$ $(\mathrm{m}, 15 \mathrm{H}, \mathrm{Ar}-\mathrm{H}), 6.62(\mathrm{~s}, 1 \mathrm{H}, \mathrm{Ar}-\mathrm{Hm}), 6.50(\mathrm{t}, J=7.20 \mathrm{~Hz}, 1 \mathrm{H}, \mathrm{Ar}-\mathrm{H}), 6.43(\mathrm{~s}, 1 \mathrm{H}, \mathrm{Ar}-\mathrm{Hm}), 5.10(\mathrm{~s}, 1 \mathrm{H}$, $-\mathrm{CH}-), 4.94(\mathrm{~s}, 1 \mathrm{H},-\mathrm{CH}-), 3.00-2.75\left(\mathrm{~m}, 4 \mathrm{H},-\mathrm{CH}_{2}-\right), 2.72\left(\mathrm{~s}, 3 \mathrm{H},-\mathrm{CH}_{3}\right), 2.65-2.60\left(\mathrm{~m}, 4 \mathrm{H},-\mathrm{CH}_{2}-\right), 1.80$ $\left(\mathrm{s}, 3 \mathrm{H},-\mathrm{CH}_{3}\right), 1.47\left(\mathrm{~s}, 3 \mathrm{H},-\mathrm{CH}_{3}\right) .{ }^{13} \mathrm{C}-\mathrm{NMR}\left(\mathrm{CDCl}_{3}, \mathrm{TMS}\right): \delta 200.2,168.6,155.3,152.3,145.6,141.3$, 141.2, 140.2, 140.0, 139.7, 139.2, 138.8, 138.4, 137.0, 131.4, 131.4, 131.2, 131.1, 131.0, 130.9, 130.4, 130.2, $129.4,128.7,127.2,127.0,126.9,126.5,126.4,126.0,125.9,125.6,125.4,124.6,124.6,122.4,57.8,56.4,32.6$, $32.4,31.9,30.4,25.6,17.9,15.9$.

\subsection{Synthesis of ligands $\mathbf{L 1}-\mathbf{L} 5 ; 2-\left\{2,4-\left(\mathrm{C}_{15} \mathrm{H}_{13}\right)_{2}-6-\mathrm{MeC}_{6} \mathrm{H}_{2} \mathrm{~N}\right\}-6-(\mathrm{ArN}) \mathrm{C}_{9} \mathrm{H}_{9} \mathrm{~N}$}

3.3.1. $\mathrm{Ar}=2,6-\mathrm{Me}_{2} \mathrm{C}_{6} \mathrm{H}_{3}$ (L1).

2,6-Dimethylaniline $(0.21 \mathrm{~g}, 1.70 \mathrm{mmol})$ was slowly added into the mixture of 2-acetyl-6[1-(2,4-bis(dibenzocycloheptyl)-6-methylphenylimino)ethyl]pyridine $(1.10 \mathrm{~g}, 1.70 \mathrm{mmol})$ and catalytic 
amount of $p$-toluenesulfonic acid $(15 \%)$ in toluene $(100 \mathrm{~mL})$. The mixture was refluxed for $8 \mathrm{~h}$ using a Dean-Stark trap. Upon completion of the reaction (checked with TLC), the mixture was cooled to room temperature and then the volatiles were evaporated at reduced pressure. The residue was purified by (basic) alumina column chromatography; elution with petroleum ether/ethyl acetate (50:2) afforded L1 as a yellow powder (0.45 g, 35\%). Mp: 256-258 ${ }^{\circ} \mathrm{C}$. FT-IR $\left(\mathrm{KBr} \mathrm{cm}^{-1}\right)$ : $3062(\mathrm{w}), 3017(\mathrm{w})$, $2933(\mathrm{w}), 2883(\mathrm{w}), 2831(\mathrm{w}), 1643(\mathrm{v}(\mathrm{C}=\mathrm{N}), \mathrm{s}), 1572(\mathrm{v}(\mathrm{C}=\mathrm{N}), \mathrm{w}), 1491(\mathrm{w}), 1449(\mathrm{~s}), 1363(\mathrm{~s}), 1300(\mathrm{w})$, $1249(\mathrm{w}), 1206(\mathrm{~m}), 1164(\mathrm{w}), 1120(\mathrm{~m}), 1097(\mathrm{w}), 1043(\mathrm{w}), 1026(\mathrm{w}), 991(\mathrm{w}), 967(\mathrm{w}), 942(\mathrm{w}), 882(\mathrm{w})$, $811(\mathrm{~m}), 773(\mathrm{~s}), 747$ (s), $710(\mathrm{~m}) .{ }^{1} \mathrm{H}-\mathrm{NMR}\left(\mathrm{CDCl}_{3}, \mathrm{TMS}\right): \delta 8.47(\mathrm{~d}, J=7.60 \mathrm{~Hz}, 2 \mathrm{H}, \mathrm{Py}-\mathrm{H}), 7.94(\mathrm{t}, J=$ $7.80 \mathrm{~Hz}, 1 \mathrm{H}, \mathrm{Py}-\mathrm{H}), 7.20-6.82(\mathrm{~m}, 18 \mathrm{H}, \mathrm{Ar}-\mathrm{H}), 6.62\left(\mathrm{~s}, 1 \mathrm{H}, \operatorname{Aryl}-\mathrm{H}_{m}\right), 6.55(\mathrm{t}, J=7.02 \mathrm{~Hz}, 1 \mathrm{H}, \mathrm{Ar}-\mathrm{H})$, $6.43\left(\mathrm{~s}, 1 \mathrm{H}\right.$, Aryl- $\left.\mathrm{H}_{m}\right), 5.12(\mathrm{~s}, 1 \mathrm{H},-\mathrm{CH}-), 4.97(\mathrm{~s}, 1 \mathrm{H},-\mathrm{CH}-), 3.13-2.90\left(\mathrm{~m}, 3 \mathrm{H},-\mathrm{CH}_{2}-\right), 2.75-2.56(\mathrm{~m}$, $\left.4 \mathrm{H},-\mathrm{CH}_{2}-\right), 2.36-2.30\left(\mathrm{~m}, 1 \mathrm{H},-\mathrm{CH}_{2}-\right), 2.18\left(\mathrm{~s}, 3 \mathrm{H},-\mathrm{CH}_{3}\right), 2.11\left(\mathrm{~s}, 3 \mathrm{H},-\mathrm{CH}_{3}\right), 2.05\left(\mathrm{~s}, 3 \mathrm{H},-\mathrm{CH}_{3}\right), 1.83(\mathrm{~s}$, $\left.3 \mathrm{H},-\mathrm{CH}_{3}\right), 1.52\left(\mathrm{~s}, 3 \mathrm{H},-\mathrm{CH}_{3}\right) .{ }^{13} \mathrm{C}-\mathrm{NMR}\left(\mathrm{CDCl}_{3}, \mathrm{TMS}\right): \delta 169.1,167.3,155.0,154.9,148.8,145.8,141.3$, $141.1,140.2,140.0,139.8,139.7,139.3,138.6,138.5,136.6,131.5,131.4,131.2,131.1,130.9,130.5,130.3$, 129.4, 128.7, 127.9, 127.1, 127.0, 126.9, 126.5, 126.3, 126.0, 125.9, 125.6, 125.5, 125.5, 124.7, 123.0, 122.3, 122.0, 57.8, 56.4, 32.5, 32.3, 31.9, 30.6, 17.9, 16.4, 16.0. Anal. calcd for $\mathrm{C}_{54} \mathrm{H}_{49} \mathrm{~N}_{3}$ (739.99): $\mathrm{C}, 87.65 ; \mathrm{H}$, 6.67; N, 5.68. Found: C, 87.48; H, 6.67; N, 5.69.

\subsection{2. $\mathrm{Ar}=2,6-\mathrm{Et}_{2} \mathrm{C}_{6} \mathrm{H}_{3}$ (L2).}

Using a similar procedure as described for the synthesis of L1, L2 was prepared as a yellow powder (0.34 g, 26\%). Mp: 215-217 ${ }^{\circ} \mathrm{C}$. FT-IR $\left(\mathrm{KBr} \mathrm{cm}^{-1}\right)$ : 3059 (w), $3015(\mathrm{w}), 2935$ (w), $2876(\mathrm{w}), 2824(\mathrm{w}), 1643$ $(v(C=N), s), 1569(v(C=N), w), 1489(w), 1448(m), 1363(m), 1302(w), 1242(w), 1219(w), 1197(w)$, $1119(\mathrm{~m}), 1100(\mathrm{w}), 1076(\mathrm{w}), 1050(\mathrm{w}), 1014(\mathrm{w}), 963(\mathrm{w}), 910(\mathrm{w}), 871(\mathrm{w}), 849(\mathrm{w}), 802(\mathrm{w}), 787(\mathrm{w})$, 759 (s), $704(\mathrm{w}) .{ }^{1} \mathrm{H}-\mathrm{NMR}\left(\mathrm{CDCl}_{3}, \mathrm{TMS}\right): \delta 8.45(\mathrm{~d}, J=8.02 \mathrm{~Hz}, 2 \mathrm{H}, \mathrm{Py}-\mathrm{H}), 7.94(\mathrm{t}, J=7.80 \mathrm{~Hz}, 1 \mathrm{H}$, Py-H), 7.20-6.81 (m, 18H, Ar-H), $6.62\left(\mathrm{~s}, 1 \mathrm{H}\right.$, Aryl- $\left.\mathrm{H}_{m}\right), 6.54(\mathrm{t}, J=7.20 \mathrm{~Hz}, 1 \mathrm{H}, \mathrm{Ar}-\mathrm{H}), 6.43(\mathrm{~s}, 1 \mathrm{H}$, Aryl- $\left.\mathrm{H}_{m}\right), 5.11(\mathrm{~s}, 1 \mathrm{H},-\mathrm{CH}-), 4.97(\mathrm{~s}, 1 \mathrm{H},-\mathrm{CH}-), 3.01-2.89\left(\mathrm{~m}, 3 \mathrm{H},-\mathrm{CH}_{2}-\right), 2.74-2.57\left(\mathrm{~m}, 5 \mathrm{H},-\mathrm{CH}_{2}-\right)$, 2.50-2.30 (m, 4H, $\left.-\mathrm{CH}_{2}-\right), 2.19\left(\mathrm{~s}, 3 \mathrm{H},-\mathrm{CH}_{3}\right), 1.83\left(\mathrm{~s}, 3 \mathrm{H},-\mathrm{CH}_{3}\right), 1.51\left(\mathrm{~s}, 3 \mathrm{H},-\mathrm{CH}_{3}\right), 1.20(\mathrm{t}, J=7.40$ $\left.\mathrm{Hz}, 3 \mathrm{H},-\mathrm{CH}_{2} \mathrm{CH}_{3}\right), 1.14\left(\mathrm{t}, J=7.40 \mathrm{~Hz}, 3 \mathrm{H},-\mathrm{CH}_{2} \mathrm{CH}_{3}\right) .{ }^{13} \mathrm{C}-\mathrm{NMR}\left(\mathrm{CDCl}_{3}, \mathrm{TMS}\right): \delta 169.1,167.0,155.0$, $154.9,147.8,145.9,141.3,141.2,140.3,140.0,139.8,139.7,139.4,138.6,138.5,136.6,131.5,131.4,131.23$, $131.12,130.99,130.52,130.29,129.44,128.71,127.14,127.02,126.87,126.50,126.30,126.0,125.9,125.6$, 124.7, 123.3, 122.3, 122.0, 57.8, 56.4, 32.5, 32.4, 31.9, 30.6, 24.7, 24.6, 17.9, 16.8, 16.1, 13.8, 13.7. Anal. calcd for $\mathrm{C}_{56} \mathrm{H}_{53} \mathrm{~N}_{3}$ (768.04): $\mathrm{C}, 87.57 ; \mathrm{H}, 6.96 ; \mathrm{N}$, 5.47. Found: $\mathrm{C}, 87.34 ; \mathrm{H}, 7.04 ; \mathrm{N}, 5.60$.

3.3.3. $\mathrm{Ar}=2,6-{ }^{i}{ }^{-} \mathrm{Pr}_{2} \mathrm{C}_{6} \mathrm{H}_{3}$ (L3).

Using a similar procedure as described for the synthesis of L1, L3 was prepared as a yellow powder (0.38 g, 28\%). Mp: 245-247 ${ }^{\circ} \mathrm{C}$. FT-IR $\left(\mathrm{KBr} \mathrm{cm}^{-1}\right)$ : $3062(\mathrm{w}), 3012(\mathrm{w}), 2960(\mathrm{~m}), 2923(\mathrm{w}), 2866(\mathrm{w}), 1649$ $(v(C=N), s), 1593(v(C=N), w), 1560(w), 1514(w), 1487(w), 1458(m), 1435(w), 1385(w), 1364(m)$, $1326(w), 1302(w), 1242(w), 1217(w), 1188(w), 1165(w), 1117(m), 1076(w), 1049(w), 1016(w)$, $960(\mathrm{w}), 934(\mathrm{w}), 905(\mathrm{w}), 879(\mathrm{w}), 841(\mathrm{w}), 815(\mathrm{w}), 789(\mathrm{w}), 769(\mathrm{~m}), 760(\mathrm{~m}), 752(\mathrm{~s}), 747(\mathrm{~s}), 721(\mathrm{w})$, $704(\mathrm{w}), 679(\mathrm{w}) .{ }^{1} \mathrm{H}-\mathrm{NMR}\left(\mathrm{CDCl}_{3}, \mathrm{TMS}\right): \delta 8.44(\mathrm{~d}, J=7.60 \mathrm{~Hz}, 2 \mathrm{H}, \mathrm{Py}-\mathrm{H}), 7.94(\mathrm{t}, J=7.80 \mathrm{~Hz}, 1 \mathrm{H}$, Py-H), 7.20-6.80 (m, 18H, Ar-H), $6.61\left(\mathrm{~s}, 1 \mathrm{H}, \mathrm{Aryl}-\mathrm{H}_{m}\right), 6.53(\mathrm{t}, J=7.20 \mathrm{~Hz}, 1 \mathrm{H}, \mathrm{Ar}-\mathrm{H}), 6.43(\mathrm{~s}, 1 \mathrm{H}$, Aryl- $\left.\mathrm{H}_{m}\right), 5.10(\mathrm{~s}, 1 \mathrm{H},-\mathrm{CH}-), 4.96(\mathrm{~s}, 1 \mathrm{H},-\mathrm{CH}-), 3.09-2.56\left(\mathrm{~m}, 9 \mathrm{H},-\mathrm{CH}_{2} /-\mathrm{CH}-\right), 2.35-2.31(\mathrm{~m}, 1 \mathrm{H}$, $\left.-\mathrm{CH}_{2}-\right), 2.20\left(\mathrm{~s}, 3 \mathrm{H},-\mathrm{CH}_{3}\right), 1.83\left(\mathrm{~s}, 3 \mathrm{H},-\mathrm{CH}_{3}\right), 1.51\left(\mathrm{~s}, 3 \mathrm{H},-\mathrm{CH}_{3}\right), 1.21\left(\mathrm{~d}, J=6.80 \mathrm{~Hz}, 6 \mathrm{H},-\mathrm{CH}\left(\mathrm{CH}_{3}\right)_{2}\right)$, $1.15\left(\mathrm{~d}, J=6.80 \mathrm{~Hz}, 6 \mathrm{H},-\mathrm{CH}\left(\mathrm{CH}_{3}\right)_{2}\right) .{ }^{13} \mathrm{C}-\mathrm{NMR}\left(\mathrm{CDCl}_{3}, \mathrm{TMS}\right): \delta 169.3,167.3,155.2,155.0,146.7,146.0$, 141.4, 141.3, 140.4, 140.2, 140.0, 139.9, 139.5, 138.8, 138.7, 136.7, 136.0, 135.9, 131.7, 131.5, 131.4, 131.2, 131.1, 131.1, 130.6, 130.4, 129.6, 128.8, 127.3, 127.1, 127.0, 126.6, 126.4, 126.1, 126.0, 125.8, 125.7, 124.8, $123.7,123.1,122.4,122.2,57.9,56.6,32.7,32.5,32.1,30.7,28.6,28.4,23.4,23.3,23.1,18.1,17.3,16.2$. Anal. calcd for $\mathrm{C}_{58} \mathrm{H}_{57} \mathrm{~N}_{3}$ (796.09): C, 87.50; H, 7.22; N, 5.28. Found: C, 87.37; H, 7.16; N, 5.36. 


\subsection{4. $\mathrm{Ar}=2,4,6-\mathrm{Me}_{3} \mathrm{C}_{6} \mathrm{H}_{2}$ (L4).}

Using a similar procedure as described for the synthesis of L1, L4 was prepared as a yellow powder (0.42 g, 32\%). Mp: 219-221 ${ }^{\circ} \mathrm{C}$. FT-IR $\left(\mathrm{KBr} \mathrm{cm}^{-1}\right)$ : 3055 (w), $3012(\mathrm{w}), 2961$ (w), 2891 (w), 2857 (w), 1640 $(v(C=N), s), 1566(v(C=N), w), 1515(w), 1482(s), 1450(w), 1433(w), 1382(w), 1359(m), 1307(w)$, $1283(\mathrm{w}), 1253(\mathrm{w}), 1217(\mathrm{~s}), 1182(\mathrm{w}), 1121(\mathrm{~m}), 1075(\mathrm{w}), 1043(\mathrm{w}), 1012(\mathrm{w}), 972(\mathrm{w}), 942(\mathrm{w}), 910(\mathrm{w})$, $886(\mathrm{w}), 851(\mathrm{~s}), 813(\mathrm{w}), 787(\mathrm{w}), 749(\mathrm{~s}), 709(\mathrm{w}), 678(\mathrm{w}) .{ }^{1} \mathrm{H}-\mathrm{NMR}\left(\mathrm{CDCl}_{3}, \mathrm{TMS}\right): \delta 8.48(\mathrm{~d}, J=7.60 \mathrm{~Hz}$, 2H, Py-H), $7.94(\mathrm{t}, J=7.80 \mathrm{~Hz}, 1 \mathrm{H}, \mathrm{Py}-\mathrm{H}), 7.21-6.83(\mathrm{~m}, 17 \mathrm{H}, \mathrm{Ar}-\mathrm{H}), 6.63\left(\mathrm{~s}, 1 \mathrm{H}\right.$, Aryl-H $\left.\mathrm{H}_{m}\right), 6.60$ $(\mathrm{t}, J=7.20 \mathrm{~Hz}, 1 \mathrm{H}, \mathrm{Ar}-\mathrm{H}), 6.44\left(\mathrm{~s}, 1 \mathrm{H}\right.$, Aryl- $\left.\mathrm{H}_{m}\right), 5.11(\mathrm{~s}, 1 \mathrm{H},-\mathrm{CH}-), 4.98(\mathrm{~s}, 1 \mathrm{H},-\mathrm{CH}-), 3.14-2.91(\mathrm{~m}$, $\left.3 \mathrm{H},-\mathrm{CH}_{2}-\right), 2.74-2.58\left(\mathrm{~m}, 5 \mathrm{H},-\mathrm{CH}_{2}-\right), 2.32\left(\mathrm{~s}, 3 \mathrm{H},-\mathrm{CH}_{3}\right), 2.18\left(\mathrm{~s}, 3 \mathrm{H},-\mathrm{CH}_{3}\right), 2.10\left(\mathrm{~s}, 3 \mathrm{H},-\mathrm{CH}_{3}\right), 2.02$ $\left(\mathrm{s}, 3 \mathrm{H},-\mathrm{CH}_{3}\right), 1.83\left(\mathrm{~s}, 3 \mathrm{H},-\mathrm{CH}_{3}\right), 1.52\left(\mathrm{~s}, 3 \mathrm{H},-\mathrm{CH}_{3}\right) .{ }^{13} \mathrm{C}-\mathrm{NMR}\left(\mathrm{CDCl}_{3}, \mathrm{TMS}\right): \delta 169.2,167.7,155.3$, 155.0, 146.4, 146.0, 141.4, 141.2, 140.4, 140.1, 140.0, 139.8, 139.5, 138.7, 138.7, 136.7, 132.3, 131.7, 131.5, 131.4, 131.2, 131.1, 130.6, 130.4, 129.6, 128.8, 128.7, 127.3, 127.1, 127.0, 126.6, 126.4, 126.1, 126.0, 125.8, 125.7, 125.4, 125.4, 124.9, 122.0, 122.1, 58.6, 57.9, 56.7, 32.7, 32.5, 32.0, 30.7, 20.9, 18.6, 18.1, 18.0, 17.9, 16.5, 16.2. Anal. calcd for $\mathrm{C}_{55} \mathrm{H}_{51} \mathrm{~N}_{3}$ (754.01): $\mathrm{C}, 87.61 ; \mathrm{H}, 6.82 ; \mathrm{N}, 5.57$. Found: $\mathrm{C}, 87.28 ; \mathrm{H}, 6.84 ; \mathrm{N}, 5.37$.

\subsection{5. $\mathrm{Ar}=2,6-\mathrm{Et}_{2}-4-\mathrm{MeC}_{6} \mathrm{H}_{2}$ (L5).}

Using a similar procedure as described for the synthesis of L1, L5 was prepared as a yellow powder (0.75 g, 54\%). Mp: 236-238 ${ }^{\circ} \mathrm{C}$. FT-IR $\left(\mathrm{KBr} \mathrm{cm}^{-1}\right)$ : $3024(\mathrm{w}), 2968(\mathrm{w}), 2939(\mathrm{w}), 2878(\mathrm{w}), 2826(\mathrm{w})$ $1647(v(C=N), s), 1567(v(C=N), w), 1522(w), 1488(w), 1457(\mathrm{~s}), 1420(\mathrm{w}), 1409(\mathrm{w}), 1366(\mathrm{~m}), 1333(\mathrm{w})$, $1307(\mathrm{w}), 1277(\mathrm{w}), 1244(\mathrm{w}), 1214(\mathrm{~s}), 1177(\mathrm{w}), 1141(\mathrm{w}), 1117(\mathrm{~m}), 1076(\mathrm{w}), 1046(\mathrm{w}), 995(\mathrm{w}), 972(\mathrm{w})$, $936(\mathrm{w}), 910(\mathrm{w}), 886(\mathrm{w}), 859(\mathrm{~s}), 829(\mathrm{~m}), 792(\mathrm{~m}), 759(\mathrm{~s}), 737(\mathrm{w}), 703(\mathrm{w}), 665(\mathrm{w}) .{ }^{1} \mathrm{H}-\mathrm{NMR}\left(\mathrm{CDCl}_{3}\right.$, TMS): $\delta 8.45$ (d, J = 8.04 Hz, 2H, Py-H), 7.94 (t, J = 7.80 Hz, 1H, Py-H), 7.21-6.82 (m, 17H, Ar-H), 6.63 $\left(\mathrm{s}, 1 \mathrm{H}\right.$, Aryl- $\left.\mathrm{H}_{m}\right), 6.55(\mathrm{t}, J=7.20 \mathrm{~Hz}, 1 \mathrm{H}, \mathrm{Ar}-\mathrm{H}), 6.44\left(\mathrm{~s}, 1 \mathrm{H}, \operatorname{Aryl}-\mathrm{H}_{m}\right), 5.11(\mathrm{~s}, 1 \mathrm{H},-\mathrm{CH}-), 4.98(\mathrm{~s}, 1 \mathrm{H}$, $-\mathrm{CH}-), 3.13-2.90\left(\mathrm{~m}, 3 \mathrm{H},-\mathrm{CH}_{2}-\right), 2.75-2.56\left(\mathrm{~m}, 4 \mathrm{H},-\mathrm{CH}_{2}-\right), 2.47-2.40\left(\mathrm{~m}, 4 \mathrm{H},-\mathrm{CH}_{2}-\right), 2.38\left(\mathrm{~s}, 3 \mathrm{H},-\mathrm{CH}_{3}\right)$, 2.36-2.26 (m, 1H, $\left.-\mathrm{CH}_{2}-\right), 2.19\left(\mathrm{~s}, 3 \mathrm{H},-\mathrm{CH}_{3}\right), 1.84\left(\mathrm{~s}, 3 \mathrm{H},-\mathrm{CH}_{3}\right), 1.52\left(\mathrm{~s}, 3 \mathrm{H},-\mathrm{CH}_{3}\right), 1.20(\mathrm{t}, J=7.60 \mathrm{~Hz}$, $\left.3 \mathrm{H},-\mathrm{CH}_{2} \mathrm{CH}_{3}\right), 1.14\left(\mathrm{t}, J=7.40 \mathrm{~Hz}, 3 \mathrm{H},-\mathrm{CH}_{2} \mathrm{CH}_{3}\right) .{ }^{13} \mathrm{C}-\mathrm{NMR}\left(\mathrm{CDCl}_{3}, \mathrm{TMS}\right): \delta 169.3,167.4,155.3,155$. 146.0, 145.4, 141.4, 141.3, 140.4, 140.1, 140.0, 139.8, 139.5, 138.7, 138.7, 136.7, 132.5, 131.7, 131.5, 131.4, 131.2, 131.1, 130.6, 130.4, 129.5, 128.8, 127.2, 127.1, 127.0, 126.9, 126.8, 126.6, 126.4, 126.1, 126.0, 125.8, 125.7, 124.9, 122.3, 122.1, 57.9, 56.6, 32.7, 32.5, 32.0, 30.7, 24.8, 24.7, 21.1, 18.6, 18.1, 16.9, 16.2, 14.0, 13.9. Anal. calcd for $\mathrm{C}_{57} \mathrm{H}_{55} \mathrm{~N}_{3}$ (782.02): C, 87.54; H, 7.09; N, 5.37. Found: $\mathrm{C}, 87.06 ; \mathrm{H}, 7.30 ; \mathrm{N}, 5.34$.

\subsection{Synthesis of complexes Co1-Co5; [2-\{2,4-( $\left.\left.\left.\mathrm{C}_{15} \mathrm{H}_{13}\right)_{2}-6-\mathrm{MeC}_{6} \mathrm{H}_{2} \mathrm{~N}\right\}-6-(\mathrm{ArN}) \mathrm{C}_{9} \mathrm{H}_{9} \mathrm{~N}\right] \mathrm{CoCl}_{2}$}

\subsection{1. $\mathrm{Co} 1\left(\mathrm{Ar}=2,6-\mathrm{Me}_{2} \mathrm{C}_{6} \mathrm{H}_{3}\right)$.}

L1 $(0.20 \mathrm{~g}, 0.27 \mathrm{mmol})$ and $\mathrm{CoCl}_{2}(0.035 \mathrm{~g}, 0.27 \mathrm{mmol})$ were loaded into a Schlenk tube, followed by the addition of dichloromethane $(5 \mathrm{~mL})$ and ethanol $(5 \mathrm{~mL})$. The mixture was stirred at room temperature for $12 \mathrm{~h}$ and then the volatiles were evaporated at reduced pressure to give concentrated solution. The complex was precipitated using diethyl ether $(20 \mathrm{~mL})$, filtered, washed with diethyl ether $(3 \times 15 \mathrm{~mL})$ and dried under reduced pressure to afford $\mathrm{Co1}$ as a green powder $0.17 \mathrm{~g}(71 \%)$. FT-IR $\left(\mathrm{KBr} \mathrm{cm}^{-1}\right)$ : $3056(\mathrm{w}), 3013(\mathrm{w}), 2927(\mathrm{w}), 2902(\mathrm{w}), 2871(\mathrm{w}), 1624(\mathrm{v}(\mathrm{C}=\mathrm{N}), \mathrm{w}), 1588(\mathrm{v}(\mathrm{C}=\mathrm{N}), \mathrm{m}), 1490(\mathrm{~m}), 1466(\mathrm{~m})$, $1447(\mathrm{~m}), 1430(\mathrm{~m}), 1368(\mathrm{~m}), 1311(\mathrm{w}), 1260(\mathrm{~m}), 1212(\mathrm{~m}), 1162(\mathrm{w}), 1128(\mathrm{w}), 1101(\mathrm{w}), 1028(\mathrm{w})$, $978(\mathrm{w}), 944(\mathrm{w}), 917(\mathrm{w}), 883(\mathrm{w}), 840(\mathrm{w}), 814(\mathrm{~m}), 790(\mathrm{w}), 760(\mathrm{~s}), 737(\mathrm{~m}), 704(\mathrm{~m}) .{ }^{1} \mathrm{H}-\mathrm{NMR}\left(\mathrm{CD}_{2} \mathrm{Cl}_{2}\right.$, TMS): $\delta 113.26\left(1 \mathrm{H}, \mathrm{Py}_{-} \mathrm{H}_{m}\right), 110.26\left(1 \mathrm{H}, \mathrm{Py}-\mathrm{H}_{m}\right), 37.57\left(1 \mathrm{H}, \mathrm{Py}-\mathrm{H}_{p}\right), 33.45(1 \mathrm{H},-\mathrm{CH}-), 27.93(1 \mathrm{H}, \mathrm{Ar}-\mathrm{H})$, $16.33(1 \mathrm{H},-\mathrm{CH}-), 9.42(1 \mathrm{H}, \mathrm{Ar}-\mathrm{H}), 8.81(1 \mathrm{H}, \mathrm{Ar}-\mathrm{H}), 8.53(1 \mathrm{H}, \mathrm{Ar}-\mathrm{H}), 8.12(1 \mathrm{H}, \mathrm{Ar}-\mathrm{H}), 7.38(1 \mathrm{H}, \mathrm{Ar}-\mathrm{H})$, 7.14-7.03 (1H, Ar-H), $6.76(1 \mathrm{H}, \mathrm{Ar}-\mathrm{H}), 6.12(1 \mathrm{H}, \mathrm{Ar}-\mathrm{H}), 5.77(1 \mathrm{H}, \mathrm{Ar}-\mathrm{H}), 5.41(1 \mathrm{H}, \mathrm{Ar}-\mathrm{H}), 4.32-4.11$ $\left(4 \mathrm{H},-\mathrm{CH}_{2}-\right), 2.17-1.97(1 \mathrm{H}, \mathrm{Ar}-\mathrm{H}), 1.17-1.15\left(4 \mathrm{H},-\mathrm{CH}_{2}-\right), 0.31(1 \mathrm{H}, \mathrm{Ar}-\mathrm{H}), 0.17(1 \mathrm{H}, \mathrm{Ar}-\mathrm{H}),-1.22(3 \mathrm{H}$, $\left.-\mathrm{CH}_{3}\right),-1.54\left(3 \mathrm{H},-\mathrm{CH}_{3}\right),-1.80\left(1 \mathrm{H}, \mathrm{Ar}-\mathrm{H}_{m}\right),-3.73\left(1 \mathrm{H}, \mathrm{Ar}-\mathrm{H}_{m}\right),-4.54(1 \mathrm{H}, \mathrm{Ar}-\mathrm{H}),-5.19(1 \mathrm{H}, \mathrm{Ar}-\mathrm{H})$, $-8.45\left(1 \mathrm{H}, \mathrm{Ar}-\mathrm{H}_{m}\right),-13.43\left(1 \mathrm{H}, \mathrm{Ar}-\mathrm{H}_{m}\right),-14.12\left(1 \mathrm{H}, \mathrm{Ar}-\mathrm{H}_{p}\right),-25.35\left(3 \mathrm{H},-\mathrm{CH}_{3}\right),-26.42\left(3 \mathrm{H},-\mathrm{CH}_{3}\right)$, 
$-29.44\left(3 \mathrm{H},-\mathrm{CH}_{3}\right)$. Anal. calcd for $\mathrm{C}_{54} \mathrm{H}_{49} \mathrm{Cl}_{2} \mathrm{CoN}_{3}$ (868.26): C, 74.56; $\mathrm{H}, 5.68 ; \mathrm{N}, 4.83$. Found: $\mathrm{C}, 75.23$; $\mathrm{H}, 5.73 ; \mathrm{N}, 4.86$.

\subsection{2. $\mathrm{Co2}\left(\mathrm{Ar}=2,6-\mathrm{Et}_{2} \mathrm{C}_{6} \mathrm{H}_{3}\right)$.}

Using the same procedure as described for the synthesis of Co1, Co2 was obtained as a green powder (0.15 g, 63\%). FT-IR $\left(\mathrm{KBr} \mathrm{cm}^{-1}\right)$ : $3060(\mathrm{w}), 3015(\mathrm{w}), 2962(\mathrm{w}), 2929(\mathrm{w}), 2874(\mathrm{w}), 2835(\mathrm{w}), 1625$ $(v(C=N), w), 1587(v(C=N), m), 1491(\mathrm{~m}), 1446(\mathrm{~m}), 1437(\mathrm{~m}), 1368(\mathrm{~m}), 1315(\mathrm{w}), 1258(\mathrm{~m}), 1211(\mathrm{~m})$, $1200(\mathrm{w}), 1130(\mathrm{w}), 1102(\mathrm{w}), 1027(\mathrm{w}), 976(\mathrm{w}), 944(\mathrm{w}), 918(\mathrm{w}), 878(\mathrm{w}), 811(\mathrm{~m}), 791(\mathrm{w}), 763(\mathrm{~s})$, $739(\mathrm{~m}), 705$ (m). ${ }^{1} \mathrm{H}-\mathrm{NMR}\left(\mathrm{CD}_{2} \mathrm{Cl}_{2}, \mathrm{TMS}\right): \delta 113.42\left(1 \mathrm{H}, \mathrm{Py}-\mathrm{H}_{m}\right), 111.18\left(1 \mathrm{H}, \mathrm{Py}-\mathrm{H}_{m}\right), 41.27\left(1 \mathrm{H}, \mathrm{Py}-\mathrm{H}_{p}\right)$, $35.41(1 \mathrm{H},-\mathrm{CH}-), 28.45(1 \mathrm{H}, \mathrm{Ar}-\mathrm{H}), 16.21(1 \mathrm{H},-\mathrm{CH}-), 10.20(1 \mathrm{H}, \mathrm{Ar}-\mathrm{H}), 9.75(1 \mathrm{H}, \mathrm{Ar}-\mathrm{H}), 9.62(1 \mathrm{H}$, Ar-H), 8.87 (1H, Ar-H), 8.25 (1H, Ar-H), 7.59 (1H, Ar-H), 6.88 (1H, Ar-H), 6.35 (2H, Ar-H), 5.93-5.78 $\left(4 \mathrm{H},-\mathrm{CH}_{2}-\right), 4.29(1 \mathrm{H}, \mathrm{Ar}-\mathrm{H}), 2.86(1 \mathrm{H}, \mathrm{Ar}-\mathrm{H}), 1.87(1 \mathrm{H}, \mathrm{Ar}-\mathrm{H}), 1.63(1 \mathrm{H}, \mathrm{Ar}-\mathrm{H}), 1.34-0.72\left(4 \mathrm{H},-\mathrm{CH}_{2}-\right)$, $0.42\left(3 \mathrm{H},-\mathrm{CH}_{3}\right), 0.06\left(3 \mathrm{H},-\mathrm{CH}_{3}\right),-1.86\left(1 \mathrm{H}, \mathrm{Ar}-\mathrm{H}_{m}\right),-3.42\left(1 \mathrm{H}, \mathrm{Ar}-\mathrm{H}_{m}\right),-5.23(1 \mathrm{H}, \mathrm{Ar}-\mathrm{H}),-6.57(1 \mathrm{H}$, Ar-H), $-6.41\left(1 \mathrm{H}, \mathrm{Ar}-\mathrm{H}_{m}\right),-11.62\left(1 \mathrm{H}, \mathrm{Ar}-\mathrm{H}_{m}\right),-12.37\left(1 \mathrm{H}, \mathrm{Ar}-\mathrm{H}_{p}\right),-17.02\left(3 \mathrm{H},-\mathrm{CH}_{3}\right),-20.34(3 \mathrm{H}$, $\left.-\mathrm{CH}_{3}\right),-26.52\left(3 \mathrm{H},-\mathrm{CH}_{3}\right),-36.20--41.91\left(4 \mathrm{H},-\mathrm{CH}_{2}-\right)$. Anal. calcd for $\mathrm{C}_{56} \mathrm{H}_{53} \mathrm{Cl}_{2} \mathrm{CoN}_{3}$ (897.88): $\mathrm{C}$, $74.91 ; \mathrm{H}, 5.95 ; \mathrm{N}, 4.68$. Found: C, 74.86; H, 5.86; N, 4.67.

\subsection{3. $\mathrm{Co} 3\left(\mathrm{Ar}=2,6{ }^{\mathrm{i}-} \mathrm{Pr}_{2} \mathrm{C}_{6} \mathrm{H}_{3}\right)$.}

Using the same procedure as described for the synthesis of Co1, Co3 was obtained as a green powder (0.16 g, 64\%). FT-IR (KBr cm $\left.{ }^{-1}\right)$ : $3063(\mathrm{w}), 3015(\mathrm{w}), 2963(\mathrm{w}), 2929(\mathrm{w}), 2872(\mathrm{w}), 2834(\mathrm{w}), 1624$ $(v(C=N), w), 1587(v(C=N), m), 1491(\mathrm{~m}), 1463(\mathrm{~m}), 1440(\mathrm{~m}), 1368(\mathrm{~m}), 1315(\mathrm{w}), 1261(\mathrm{~m}), 1217(\mathrm{w})$, $1161(w), 1134(w), 1102(w), 1048(w), 1027(w), 977(w), 942(w), 918(w), 881(w), 840(w), 812(w)$, $792(\mathrm{w}), 763(\mathrm{~s}), 749(\mathrm{~s}), 709(\mathrm{~m}), 652(\mathrm{~m}) .{ }^{1} \mathrm{H}-\mathrm{NMR}\left(\mathrm{CD}_{2} \mathrm{Cl}_{2}, \mathrm{TMS}\right): \delta 115.71\left(1 \mathrm{H}, \mathrm{Py}-\mathrm{H}_{m}\right), 113.06(1 \mathrm{H}$, Py- $\left.\mathrm{H}_{m}\right), 48.23\left(1 \mathrm{H}, \mathrm{Py}-\mathrm{H}_{p}\right), 38.18(1 \mathrm{H},-\mathrm{CH}-), 36.40(1 \mathrm{H}, \mathrm{Ar}-\mathrm{H}), 18.39(1 \mathrm{H},-\mathrm{CH}-), 13.36(1 \mathrm{H}, \mathrm{Ar}-\mathrm{H})$, $11.45(1 \mathrm{H}, \mathrm{Ar}-\mathrm{H}), 10.55(1 \mathrm{H}, \mathrm{Ar}-\mathrm{H}), 9.67(1 \mathrm{H}, \mathrm{Ar}-\mathrm{H}), 8.74(1 \mathrm{H}, \mathrm{Ar}-\mathrm{H}), 7.55(2 \mathrm{H}, \mathrm{Ar}-\mathrm{H}), 7.15(1 \mathrm{H}, \mathrm{Ar}-\mathrm{H})$, $6.76(1 \mathrm{H}, \mathrm{Ar}-\mathrm{H}), 6.18-5.91\left(4 \mathrm{H},-\mathrm{CH}_{2}-\right), 4.69(1 \mathrm{H}, \mathrm{Ar}-\mathrm{H}), 3.60(1 \mathrm{H}, \mathrm{Ar}-\mathrm{H}), 3.19(3 \mathrm{H}, \mathrm{Ar}-\mathrm{H}), 2.57(1 \mathrm{H}$, $-\mathrm{CH}-), 1.90(1 \mathrm{H},-\mathrm{CH}-), 1.33-0.83\left(4 \mathrm{H},-\mathrm{CH}_{2}-\right),-1.23\left(1 \mathrm{H}, \mathrm{Ar}-\mathrm{H}_{m}\right),-2.37\left(3 \mathrm{H},-\mathrm{CH}_{3}\right),-2.86\left(3 \mathrm{H},-\mathrm{CH}_{3}\right)$, $-3.27\left(3 \mathrm{H},-\mathrm{CH}_{3}\right),-5.23\left(1 \mathrm{H}, \mathrm{Ar}-\mathrm{H}_{m}\right),-7.03\left(1 \mathrm{H}, \mathrm{Ar}-\mathrm{H}_{m}\right),-9.10\left(1 \mathrm{H}, \mathrm{Ar}-\mathrm{H}_{m}\right),-11.56(1 \mathrm{H}, \mathrm{Ar}-\mathrm{H}),-13.45$ $\left(3 \mathrm{H},-\mathrm{CH}_{3}\right),-14.56\left(1 \mathrm{H}, \mathrm{Ar}-\mathrm{H}_{p}\right),-24.03\left(3 \mathrm{H},-\mathrm{CH}_{3}\right),-26.77\left(3 \mathrm{H},-\mathrm{CH}_{3}\right),-31.49\left(3 \mathrm{H},-\mathrm{CH}_{3}\right)$. Anal. calcd for $\mathrm{C}_{58} \mathrm{H}_{57} \mathrm{Cl}_{2} \mathrm{CoN}_{3}$ (925.93): C, 75.23; $\mathrm{H}, 6.26 ; \mathrm{N}, 4.54$. Found: $\mathrm{C}, 74.96 ; \mathrm{H}, 6.18 ; \mathrm{N}, 4.49$.

\subsection{4. $\mathrm{Co} 4\left(\mathrm{Ar}=2,4,6-\mathrm{Me}_{3} \mathrm{C}_{6} \mathrm{H}_{2}\right)$.}

Using the same procedure as described for the synthesis of Co1, Co4 was obtained as a green powder (0.16 g, 67\%). FT-IR (KBr cm $\left.{ }^{-1}\right)$ : $3055(\mathrm{w}), 3014(\mathrm{w}), 2960(\mathrm{w}), 2923(\mathrm{w}), 2875(\mathrm{w}), 2834(\mathrm{w}), 1624$ $(v(C=N), w), 1587(v(C=N), m), 1489(m), 1437(m), 1368(m), 1313(\mathrm{w}), 1260(\mathrm{~m}), 1217(\mathrm{~m}), 1158(\mathrm{w})$, $1130(\mathrm{w}), 1101(\mathrm{w}), 1026(\mathrm{w}), 978(\mathrm{w}), 943(\mathrm{w}), 917(\mathrm{w}), 880(\mathrm{w}), 847(\mathrm{w}), 808(\mathrm{w}), 762(\mathrm{~s}), 749(\mathrm{~s}), 705(\mathrm{~m})$. ${ }^{1} \mathrm{H}-\mathrm{NMR}\left(\mathrm{CD}_{2} \mathrm{Cl}_{2}\right.$, TMS $): \delta 112.64\left(1 \mathrm{H}, \mathrm{Py}-\mathrm{H}_{m}\right), 110.65\left(1 \mathrm{H}, \mathrm{Py}-\mathrm{H}_{m}\right), 38.06\left(1 \mathrm{H}, \mathrm{Py}-\mathrm{H}_{p}\right), 33.50(1 \mathrm{H}$, $-\mathrm{CH}-), 27.51(1 \mathrm{H}, \mathrm{Ar}-\mathrm{H}), 17.56\left(3 \mathrm{H}_{p},-\mathrm{CH}_{3}\right), 15.94(1 \mathrm{H},-\mathrm{CH}-), 9.41(1 \mathrm{H}, \mathrm{Ar}-\mathrm{H}), 8.85-8.76\left(4 \mathrm{H},-\mathrm{CH}_{2}-\right)$, $8.07(1 \mathrm{H}, \mathrm{Ar}-\mathrm{H}), 7.40(1 \mathrm{H}, \mathrm{Ar}-\mathrm{H}), 6.75(1 \mathrm{H}, \mathrm{Ar}-\mathrm{H}), 6.16(1 \mathrm{H}, \mathrm{Ar}-\mathrm{H}), 5.79(1 \mathrm{H}, \mathrm{Ar}-\mathrm{H}), 5.46(1 \mathrm{H}, \mathrm{Ar}-\mathrm{H})$, 4.58-4.44 (2H, Ar-H), $4.18(1 \mathrm{H}, \mathrm{Ar}-\mathrm{H}), 2.23(1 \mathrm{H}, \mathrm{Ar}-\mathrm{H}), 1.32-1.15\left(4 \mathrm{H},-\mathrm{CH}_{2}-\right), 0.42(1 \mathrm{H}, \mathrm{Ar}-\mathrm{H}), 0.04(1 \mathrm{H}$, Ar-H), $-0.89\left(3 \mathrm{H},-\mathrm{CH}_{3}\right),-1.09\left(3 \mathrm{H},-\mathrm{CH}_{3}\right),-1.72\left(1 \mathrm{H}, \mathrm{Ar}-\mathrm{H}_{m}\right),-3.70\left(1 \mathrm{H}, \mathrm{Ar}-\mathrm{H}_{m}\right),-4.93(1 \mathrm{H}, \mathrm{Ar}-\mathrm{H})$, $-5.20(1 \mathrm{H}, \mathrm{Ar}-\mathrm{H}),-7.45\left(1 \mathrm{H}, \mathrm{Ar}-\mathrm{H}_{m}\right),-12.95\left(1 \mathrm{H}, \mathrm{Ar}-\mathrm{H}_{m}\right),-24.36\left(3 \mathrm{H},-\mathrm{CH}_{3}\right),-25.57\left(3 \mathrm{H},-\mathrm{CH}_{3}\right)$, $-28.79\left(3 \mathrm{H},-\mathrm{CH}_{3}\right)$. Anal. calcd for $\mathrm{C}_{55} \mathrm{H}_{51} \mathrm{Cl}_{2} \mathrm{CoN}_{3}$ (883.85): C, 74.74; $\mathrm{H}, 5.82 ; \mathrm{N}, 4.75$. Found: $\mathrm{C}, 74.73$; $\mathrm{H}, 5.84 ; \mathrm{N}, 4.58$.

\subsection{5. $\operatorname{Co5}\left(\mathrm{Ar}=2,6-\mathrm{Et}_{2}-4-\mathrm{MeC}_{6} \mathrm{H}_{2}\right)$.}

Using the same procedure as described for the synthesis of Co1, Co5 was obtained as a green powder (0.17 g, 68\%). FT-IR (KBr cm $\left.{ }^{-1}\right): 3053(w), 3014(w), 2963(w), 2927(w), 2874(w), 2834(w), 1624$ 
$(v(C=N), w), 1587(v(C=N), m), 1491(m), 1452(m), 1368(\mathrm{~m}), 1315(\mathrm{w}), 1260(\mathrm{~m}), 1215(\mathrm{~m}), 1156(\mathrm{w})$, $1127(\mathrm{w}), 1100(\mathrm{w}), 1027(\mathrm{w}), 978(\mathrm{w}), 943(\mathrm{w}), 916(\mathrm{w}), 880(\mathrm{w}), 857(\mathrm{w}), 811(\mathrm{~m}), 763(\mathrm{~s}), 750(\mathrm{~s}), 704(\mathrm{~m})$. ${ }^{1} \mathrm{H}-\mathrm{NMR}\left(\mathrm{CD}_{2} \mathrm{Cl}_{2}, \mathrm{TMS}\right): \delta 112.95\left(1 \mathrm{H}, \mathrm{Py}-\mathrm{H}_{m}\right), 111.60\left(1 \mathrm{H}, \mathrm{Py}-\mathrm{H}_{m}\right), 41.33\left(1 \mathrm{H}, \mathrm{Py}-\mathrm{H}_{p}\right), 35.50(1 \mathrm{H}$, $-\mathrm{CH}-), 27.84(1 \mathrm{H}, \mathrm{Ar}-\mathrm{H}), 18.63\left(3 \mathrm{H}_{p},-\mathrm{CH}_{3}\right), 16.03(1 \mathrm{H},-\mathrm{CH}-), 10.08(1 \mathrm{H}, \mathrm{Ar}-\mathrm{H}), 9.75(2 \mathrm{H}, \mathrm{Ar}-\mathrm{H}), 8.72$ (1H, Ar-H), 8.17 (1H, Ar-H), 7.65 (1H, Ar-H), $6.82(2 \mathrm{H}, \mathrm{Ar}-\mathrm{H}), 6.40-6.23\left(4 \mathrm{H},-\mathrm{CH}_{2}-\right), 5.90-5.58(4 \mathrm{H}$, $\left.-\mathrm{CH}_{2}-\right), 4.21(1 \mathrm{H}, \mathrm{Ar}-\mathrm{H}), 2.82(1 \mathrm{H}, \mathrm{Ar}-\mathrm{H}), 1.75-1.04(3 \mathrm{H}, \mathrm{Ar}-\mathrm{H}), 0.70\left(3 \mathrm{H},-\mathrm{CH}_{3}\right), 0.49\left(3 \mathrm{H},-\mathrm{CH}_{3}\right),-0.16$ $\left(1 \mathrm{H}, \mathrm{Ar}-\mathrm{H}_{m}\right),-3.45\left(1 \mathrm{H}, \mathrm{Ar}-\mathrm{H}_{m}\right),-5.63(1 \mathrm{H}, \mathrm{Ar}-\mathrm{H}),-6.87(1 \mathrm{H}, \mathrm{Ar}-\mathrm{H}),-7.51\left(1 \mathrm{H}, \mathrm{Ar}-\mathrm{H}_{m}\right),-12.62(1 \mathrm{H}$, $\left.\mathrm{Ar}-\mathrm{H}_{m}\right),-17.06\left(3 \mathrm{H},-\mathrm{CH}_{3}\right),-20.66\left(3 \mathrm{H},-\mathrm{CH}_{3}\right),-24.84\left(3 \mathrm{H},-\mathrm{CH}_{3}\right),-32.25--44.93\left(4 \mathrm{H},-\mathrm{CH}_{2}-\right)$. Anal. calcd for $\mathrm{C}_{57} \mathrm{H}_{55} \mathrm{Cl}_{2} \mathrm{CoN}_{3}$ (911.91): C, 75.07; H, 6.08; N, 4.61. Found: C, 75.01; H, 6.16; N, 4.57.

\subsection{X-Ray Crystallographic Studies}

Single crystal X-ray diffraction analysis of Co3 and Co4 was carried out on a Saturn 724+ CCD diffractometer (Rigaku, Tokyo, Japan) with the graphite-monochromated Mo-K $\alpha$ radiation $(\lambda=0.71073 \AA)$ at 173(2) $\mathrm{K}$ and cell parameters were obtained by global refinement of the positions of all collected reflections. Intensities were corrected for Lorentz and polarization effects, and an empirical absorption. The structures were solved by direct methods and refined by full-matrix least-squares on $F^{2}$. All hydrogen atoms were placed in calculated positions. Structural solution of each complex and refinement were performed by SHELXT $[67,68]$. In the structural solution of each crystal, two identical structures were found. The solvent molecules which have no effect on the geometry of the main compound were also processed by using SHELXT $[67,68]$. All hydrogen atoms and one identical molecule of the complex have been omitted in the ORTEP diagrams for clarity. Crystal data and processing parameters for Co3 and Co4 are summarized in Table 7.

Table 7. Crystal data and structure refinement for the Co3 and Co4 complexes.

\begin{tabular}{|c|c|c|}
\hline Identification Code & Co3 & $\mathrm{Co} 4$ \\
\hline CCDC number & 1905876 & 1905877 \\
\hline Empirical formula & $2\left(\mathrm{C}_{58} \mathrm{H}_{56} \mathrm{Cl}_{2} \mathrm{CoN}_{3}\right)$ & $2\left(\mathrm{C}_{55} \mathrm{H}_{50} \mathrm{Cl}_{2} \mathrm{CoN}_{3}\right)$ \\
\hline Formula weight & 924.88 & 883.31 \\
\hline Temperature (K) & 173.1500 & 173.1500 \\
\hline Wavelength (̊) & 0.71073 & 0.71073 \\
\hline Crystal system & monoclinic & orthorhombic \\
\hline Space group & $P 21 / c$ & Pna21 \\
\hline a $(\AA)$ & $26.6132(7)$ & $16.5906(3)$ \\
\hline b (̊̊) & $24.0122(6)$ & 12.1091(3) \\
\hline$c(\AA)$ & $17.1072(4)$ & 49.9111(9) \\
\hline$\alpha\left(^{\circ}\right)$ & 90 & 90 \\
\hline$\beta\left(^{\circ}\right)$ & 105.153(3) & 90 \\
\hline$\gamma\left({ }^{\circ}\right)$ & 90 & 90 \\
\hline Volume $\left(\AA^{3}\right)$ & 10552.1(5) & 10027.0(4) \\
\hline $\mathrm{Z}$ & 8 & 4 \\
\hline D calcd $\left(\mathrm{g} / \mathrm{cm}^{3}\right)$ & 1.164 & 1.170 \\
\hline$\mu\left(\mathrm{mm}^{-1}\right)$ & 0.464 & 0.486 \\
\hline$F(000)$ & 3888.0 & 3700.0 \\
\hline Crystal size $\left(\mathrm{mm}^{3}\right)$ & $0.376 \times 0.105 \times 0.082$ & $0.476 \times 0.118 \times 0.056$ \\
\hline$\theta$ range $\left(^{\circ}\right)$ & 2.994 to 50 & $\begin{array}{c}3.264 \text { to } 55 \\
-21 \leq \mathrm{h} \leq 21\end{array}$ \\
\hline Limiting indexes & $\begin{array}{l}-31 \leq \mathrm{h} \leq 31 \\
-28 \leq \mathrm{k} \leq 28 \\
-20 \leq 1 \leq 20\end{array}$ & $\begin{array}{l}-15 \leq \mathrm{k} \leq 15 \\
-64 \leq 1 \leq 64\end{array}$ \\
\hline No. of rflns collected & 121754 & 135076 \\
\hline No. of unique rflns [R(int)] & $18602(0.1031)$ & $23020(0.0956)$ \\
\hline Completeness to $\theta(\%)$ & 1.00 & 1.98 \\
\hline Data/restraints/parameters & $18602 / 445 / 1167$ & 23020/177/1149 \\
\hline Goodness of fit on $F^{2}$ & 1.041 & 0.988 \\
\hline Final $\mathrm{R}$ indexes $[I>=2 \sigma(I)]$ & $\begin{array}{c}\mathrm{R}_{1}=0.0965 \\
\mathrm{wR}_{2}=0.2394\end{array}$ & $\begin{array}{r}\mathrm{R}_{1}=0.0691 \\
\mathrm{wR}_{2}=0.1588\end{array}$ \\
\hline $\mathrm{R}$ indexes (all data) & $\begin{array}{c}\mathrm{R}_{1}=0.1397 \\
\mathrm{wR}_{2}=0.2729\end{array}$ & $\begin{array}{c}\mathrm{R}_{1}=0.1134 \\
\mathrm{wR}_{2}=0.1841\end{array}$ \\
\hline Largest diff. peak and hole $\left(\mathrm{e} \AA^{-3}\right)$ & $1.36 /-0.82$ & $0.60 /-0.28$ \\
\hline
\end{tabular}




\subsection{General Procedure for Ethylene Polymerization under 5/10 atm Pressure}

Ethylene polymerization is conducted in a stainless-steel autoclave $(250 \mathrm{~mL})$ equipped with the temperature and pressure control system and a mechanical stirrer. The autoclave is initially evacuated and then filled with nitrogen gas. This process is repeated three times and after the final evacuation ethylene is introduced. A solution of the corresponding complex $(1.5 \mu \mathrm{mol})$ in freshly distilled toluene $(25 \mathrm{~mL})$ is injected into the autoclave. Another batch of freshly distilled toluene $(25 \mathrm{~mL})$ is added and then the required amount of a cocatalyst (MAO, or MMAO) is injected. After adding another batch of toluene $(50 \mathrm{~mL})$, the autoclave is pressurized immediately with ethylene $(10 \mathrm{~atm})$ and the contents is stirred at a rate of $400 \mathrm{rpm}$. Upon completion, the stirring is stopped and the pressure is slowly released. The reaction is quenched with $10 \%$ hydrochloric acid in ethanol, and the polymer is washed with ethanol, filtered and dried under reduced pressure at $40{ }^{\circ} \mathrm{C}$. Finally, the product is weighed. Schlenk tube is used instead of autoclave for ethylene polymerization at $1 \mathrm{~atm}$, following similar procedure.

\section{Conclusions}

The successful incorporation of dibenzocycloheptyl groups at the 2- and 4-positions of one of the aryl rings attached to the imine nitrogen atom in the generic bis(imino)pyridine yielded an unsymmetrical species, which was further modified through variations in the second aryl group, leading to the L1-L5 ligands. The ligands were used to generate the corresponding cobalt(II) chloride precatalysts Co1-Co5. The characterization procedure included single-crystal X-ray diffraction analysis for $\mathrm{Co} 3$ and Co4. Activated with either MAO or MMAO, all the title complexes displayed high activity and thermal stability in ethylene polymerization up to $60^{\circ} \mathrm{C}$. The least sterically encumbered precatalyst Co1 reached the peak activity of $1.00 \times 10^{7} \mathrm{~g} \mathrm{PE} \mathrm{mol}^{-1}(\mathrm{Co}) \mathrm{h}^{-1}$ with MAO at $60^{\circ} \mathrm{C}$ and $7.89 \times 10^{6} \mathrm{~g} \mathrm{PE} \mathrm{mol}^{-1}(\mathrm{Co}) \mathrm{h}^{-1}$ with MMAO at $50^{\circ} \mathrm{C}$, which suggests high thermal stability of the active sites. Notably, the most sterically hindered precatalyst $\mathrm{Co} 3$ has the propensity to generate polyethylene of the highest molecular weight. The catalytic system maintains good activity of $4.10 \times 10^{6} \mathrm{~g}$ PE $\mathrm{mol}^{-1}(\mathrm{Co}) \mathrm{h}^{-1}$ at the temperature as high as $80^{\circ} \mathrm{C}$. Therefore, we believe that it might be considered as a potential candidate for the industrial polymerization process, where the quest for novel precatalysts generating active and thermally stable active sites still encounters obstacles difficult to overcome.

Supplementary Materials: The following are available online at http://www.mdpi.com/1420-3049/24/10/2007/s1, Figure S1: ${ }^{1} \mathrm{H}$ NMR spectrum of $\mathrm{Co1}$ in $\mathrm{CD}_{2} \mathrm{Cl}_{2}$ at room temperature. Figure S2: ${ }^{1} \mathrm{H}$ NMR spectrum of $\mathbf{C o 2}$ in $\mathrm{CD}_{2} \mathrm{Cl}_{2}$ at room temperature. Figure S3: ${ }^{1} \mathrm{H}$ NMR spectrum of $\mathrm{Co} 3$ in $\mathrm{CD}_{2} \mathrm{Cl}_{2}$ at room temperature. Figure S4: ${ }^{1} \mathrm{H}$ NMR spectrum of $\mathrm{Co} 4$ in $\mathrm{CD}_{2} \mathrm{Cl}_{2}$ at room temperature. Figure S5: ${ }^{1} \mathrm{H}$ NMR spectrum of $\mathrm{Co} 5$ in $\mathrm{CD}_{2} \mathrm{Cl}_{2}$ at room temperature. Figure S6: GPC curves of the obtained polyethylene (a); activity and $M_{\mathrm{w}}$ as a function of reaction temperature (b) for the Co1/MMAO system (Table 5, entries 1-7). Figure S7: GPC curves of the obtained polyethylene (a); activity and $M_{\mathrm{w}}$ as a function of $\mathrm{Al} / \mathrm{Co}$ ratio (b) for the Co1/MMAO system (Table 5, entries 3 and $8-13)$. Figure S8: GPC curves of the obtained polyethylene (a); activity and $M_{\mathrm{w}}$ as a function of run time (b) for the Co1/MMAO system (Table 5, entries 10 and 14-17). Figure S9: GPC curves of the obtained polyethylene (a); activity and $M_{\mathrm{w}}$ for different precatalysts (b) at the optimized reaction conditions with MMAO as cocatalyst (Table 6, entries $1-5$ ). Figure S10: GPC curves of the obtained polyethylene (a); activity and $M_{\mathrm{W}}$ as a function of ethylene pressure (b) at the optimized reaction conditions for the Co1/MMAO system (Table 5, entries 10, 18 and 19). Figure S11: The ${ }^{1} \mathrm{H}$ NMR spectrum of the polyethylene obtained with Co1/MMAO (Table 5, entry 10). Figure S12: The ${ }^{13} \mathrm{C}$ NMR spectrum of the polyethylene obtained with Co1/MMAO (Table 5, entry 10). Table S1: The selected bond lengths ( $\AA$ ) and angles $\left({ }^{\circ}\right)$ for the $B$ molecules of Co3 and Co4.

Author Contributions: Design of the study and experiments, W.-H.S. and W.Z.; synthesis and catalysis, M.Z., manuscript, M.Z., L.G. and Z.F.; interpretation of the data obtained from the single crystal X-ray diffraction, Y.S.; chemical support, Y.M. and W.Z.

Funding: This work was funded by the National Natural Science Foundation of China (No. 21871275 and 51473170).

Acknowledgments: M.Z. is thankful to CAS-TWAS President's Fellowship, and Z.F. thanks the Chinese Academy of Sciences President's International Fellowship Initiative.

Conflicts of Interest: The authors declare no conflict of interest. 


\section{References}

1. Small, B.L.; Brookhart, M.; Bennett, A.M.A. Highly Active Iron and Cobalt Catalysts for the Polymerization of Ethylene. J. Am. Chem. Soc. 1998, 120, 4049-4050. [CrossRef]

2. Britovsek, G.J.P.; Gibson, V.C.; Kimberley, B.S.; Maddox, P.J.; McTavish, S.J.; Solan, G.A.; White, A.J.P.; Williams, D.J. Novel olefin polymerization catalysts based on iron and cobalt. Chem. Commun. 1998, 7, 849-850. [CrossRef]

3. Johnson, L.K.; Killian, C.M.; Brookhart, M. New Pd(I1)- and Ni(I1)-Based Catalysts for Polymerization of Ethylene and a-Olefins. J. Am. Chem. Soc. 1995, 117, 6414-6415. [CrossRef]

4. Killian, C.M.; Tempel, D.J.; Johnson, L.K.; Brookhart, M. Living Polymerization of r-Olefins Using NiII-r-Diimine Catalysts. Synthesis of New Block Polymers Based on r-Olefins. J. Am. Chem. Soc. 1996, 118, 11664-11665. [CrossRef]

5. Wang, Z.; Liu, Q.; Solan, G.A.; Sun, W.-H. Recent advances in Ni-mediated ethylene chain growth: Nimine-donor ligand effects on catalytic activity, thermal stability and oligo-/polymer structure. Coord. Chem. Rev. 2017, 350, 68-83. [CrossRef]

6. Edgecombe, B.D.; Stein, J.A.; Frechet, J.M.J. The Role of Polymer Architecture in Strengthening Polymer-Polymer Interfaces: A Comparison of Graft, Block, and Random Copolymers Containing Hydrogen-Bonding Moieties. Macromolecules 1998, 31, 1292-1304. [CrossRef]

7. Harth, E.M.; Hecht, S.; Helms, B.; Malmstrom, E.E.; Frechet, J.M.J.; Hawker, C.J. The Effect of Macromolecular Architecture in Nanomaterials: A Comparison of Site Isolation in Porphyrin Core Dendrimers and Their Isomeric Linear Analogues. J. Am. Chem. Soc. 2002, 124, 3926-3938. [CrossRef]

8. Wang, Z.; Solan, G.A.; Zhang, W.; Sun, W.-H. Carbocyclic-fused N,N,N-pincer ligands as ring-strain adjustable supports for iron and cobalt catalysts in ethylene oligo-/polymerization. Coord. Chem. Rev. 2018, 363, 92-108. [CrossRef]

9. Zhang, W.; Sun, W.-H.; Redshaw, C. Tailoring iron complexes for ethylene oligomerization and/or polymerization. Dalton Trans. 2013, 42, 8988-8997. [CrossRef]

10. Ma, J.; Feng, C.; Wang, S.; Zhao, K.-Q.; Sun, W.-H.; Redshaw, C.; Solan, G.A. Bi- and tri-dentate imino-based iron and cobalt pre-catalysts for ethylene oligo-/polymerization. Inorg. Chem. Front. 2014, 1, 14-34. [CrossRef]

11. Flisak, Z.; Sun, W.-H. Progression of Diiminopyridines: From Single Application to Catalytic Versatility. ACS Catal. 2015, 5, 4713-4724. [CrossRef]

12. Britovsek, G.J.P.; Gibson, V.C.; Kimberley, B.S.; Mastroianni, S.; Redshaw, C.; Solan, G.A.; White, A.J.P.; Williams, D.J. Cationic 2,6-bis(imino)pyridine iron and cobalt complexes: Synthesis, structures, ethylene polymerisation and ethylene/polar monomer co-polymerisation studies. J. Chem. Soc. Dalton Trans. 2001, 6, 1639-1644. [CrossRef]

13. Yue, E.; Zeng, Y.; Zhang, W.; Sun, Y.; Cao, X.-P.; Sun, W.-H. Highly linear polyethylenes using the 2-(1-(2,4-dibenzhydrylnaphthylimino)ethyl)-6-(1-(arylimino)ethyl)pyridylcobalt chlorides: Synthesis, characterization and ethylene polymerization. Sci. China. Chem. 2016, 59, 1291-1300. [CrossRef]

14. Yang, W.; Yi, J.; Ma, Z.F.; Sun, W.-H. 2D-QSAR modeling on the catalytic activities of 2-azacyclyl6aryliminopyridylmetal precatalysts in ethylene oligomerization. Catal. Commun. 2017, 101, 40-43. [CrossRef]

15. Bariashir, C.; Wang, Z.; Du, S.; Solan, G.A.; Huang, C.; Liang, T.; Sun, W.-H. Cycloheptyl-Fused NNO-Ligands as Electronically Modifiable Supports for M(II) (M5Co, Fe) Chloride Precatalysts; Probing Performance in Ethylene Oligo-/Polymerization. J. Polym. Sci. Part A Polym. Chem. 2017, 55, 3980-3989. [CrossRef]

16. Chen, Q.; Suo, H.; Zhang, W.; Zhang, R.; Solan, G.A.; Liang, T.; Sun, W.-H. 1,5-Naphthyl-linked bis(imino)pyridines as binucleating scaffolds for dicobalt ethylene oligo-/polymerization catalysts: Exploring temperature and steric effects. Dalton Trans. 2019, in press. [CrossRef] [PubMed]

17. Smit, T.M.; Tomov, A.K.; Britovsek, G.J.P.; Gibson, V.C.; White, A.J.P.; Williams, D.J. The effect of imine-carbon substituents in bis(imino)pyridine-based ethylene polymerisation catalysts across the transition series. Catal. Sci. Technol. 2012, 2, 643-655. [CrossRef]

18. Sun, W.H.; Hao, P.; Li, G.; Zhang, S.; Wang, W.Q.; Yi, J.J.; Asma, M.; Tang, N. Synthesis and Characterization of Iron and Cobalt Dichloride Bearing 2-Quinoxalinyl- 6-Iminopyridines and Their Catalytic Behavior toward Ethylene Reactivity. J. Organomet. Chem. 2007, 692, 4506-4518. [CrossRef] 
19. Gao, R.; Li, Y.; Wang, F.; Sun, W.-H.; Bochmann, M. 2-Benzoxazolyl-6-[1-(arylimino)ethyl]pyridyliron(II) Chlorides as Ethylene Oligomerization Catalysts. Eur. J. Inorg. Chem. 2009, 27, 4149-4156. [CrossRef]

20. Sun, W.-H.; Hao, P.; Zhang, S.; Shi, Q.; Zuo, W.; Tang, X.; Lu, X. Synthesis and characterization of iron and cobalt dichloride bearing 2-quinoxalinyl-6-iminopyridines and their catalytic behavior toward ethylene reactivity. Organometallics 2007, 26, 2720-2734. [CrossRef]

21. Wang, K.; Wedeking, K.; Zuo, W.; Zhang, D.; Sun, W.-H. Iron(II) and cobalt(II) complexes bearing N-((pyridin2-yl)methylene)-quinolin-8-amine derivatives: Synthesis and application to ethylene oligomerization. $J$. Organomet. Chem. 2008, 693, 1073-1080. [CrossRef]

22. Wang, L.; Sun, W.H.; Han, L.; Yang, H.; Hu, Y.; Jin, X. Late transition metal complexes bearing 2,9-bis(imino)1,10phenanthrolinyl ligands: Synthesis, characterization and their ethylene activity. J. Organomet. Chem. 2002, 658, 62-70. [CrossRef]

23. Sun, W.-H.; Jie, S.; Zhang, S.; Zhang, W.; Song, Y.; Ma, H. Iron Complexes Bearing 2-Imino-1,10-phenanthrolinyl Ligands as Highly Active Catalysts for Ethylene Oligomerization. Organometallics 2006, 25, 666-677. [CrossRef]

24. Pelletier, J.D.A.; Champouret, Y.D.M.; Cadarso, J.; Clowes, L.; Gañete, M.; Singh, K.; Thanarajasingham, V.; Solan, G.A. Electronically variable imino-phenanthrolinyl-cobalt complexes; synthesis, structures and ethylene oligomerisation studies. J. Organomet. Chem. 2006, 691, 4114-4123. [CrossRef]

25. Jie, S.; Zhang, S.; Wedeking, K.; Zhang, W.; Ma, H.; Lu, X.; Deng, Y.; Sun, W.-H. Cobalt(II) complexes bearing 2-imino-1,10-phenanthroline ligands: Synthesis, characterization and ethylene oligomerization. C.R. Chimie 2006, 9, 1500-1509. [CrossRef]

26. Jie, S.; Zhang, S.; Sun, W.H.; Kuang, X.; Liu, T.; Guo, J. Iron(II) complexes ligated by 2-imino-1,10-phenanthrolines: Preparation and catalytic behavior toward ethylene oligomerization. J. Mol. Catal. A Chem. 2007, 269, 85-96. [CrossRef]

27. Jie, S.; Zhang, S.; Sun, W.H. 2-Arylimino-9-phenyl-1,10-phenanthrolinyl-iron, -cobalt and -nickel Complexes: Synthesis, Characterization and Ethylene Oligomerization Behavior. Eur. J. Inorg. Chem. 2007, 35, 5584-5598. [CrossRef]

28. Xiao, L.; Gao, R.; Zhang, M.; Li, Y.; Cao, X.; Sun, W.-H. 2-(1H-2-Benzimidazolyl)-6-(1-(arylimino)ethyl)pyridyl Iron(II) and Cobalt(II) Dichlorides: Syntheses, Characterizations, and Catalytic Behaviors toward Ethylene Reactivity. Organometallics 2009, 28, 2225-2233. [CrossRef]

29. Appukuttan, V.K.; Liu, Y.; Son, B.C.; Ha, C.-S.; . Suh, H.; Kim, I. Iron and Cobalt Complexes of 2,3,7,8-Tetrahydroacridine-4,5(1H,6H)-diimine Sterically Modulated by Substituted Aryl Rings for the Selective Oligomerization to Polymerization of Ethylene. Organometallics 2011, 30, 2285-2294. [CrossRef]

30. Zhang, W.; Chai, W.; Sun, W.-H.; Hu, X.; Redshaw, C.; Hao, X. 2-(1-(Arylimino)ethyl)-8-arylimino-5,6,7-trihydroquinoline Iron(II) Chloride Complexes: Synthesis, Characterization, and Ethylene Polymerization Behavior. Organometallics 2012, 31, 5039-5048. [CrossRef]

31. Sun, W.-H.; Kong, S.; Chai, W.; Shiono, T.; Redshaw, C.; Hu, X.; Guo, C.; Hao, X. 2-(1-(Arylimino)ethyl)-8arylimino-5,6,7-trihydroquinolylcobalt dichloride: Synthesis and polyethylene wax formation. Appl. Catal. A. 2012, 447, 67-73. [CrossRef]

32. Huang, F.; Xing, Q.; Liang, T.; Flisak, Z.; Ye, B.; Hu, X.; Yang, W.; Sun, W.H. 2-(1-Aryliminoethyl)9-arylimino-5,6,7,8-tetrahydrocycloheptapyridyl iron(II) dichloride: Synthesis, characterization, and the highly active and tunable active species in ethylene polymerization. Dalton Trans. 2014, 43, 16818-16829. [CrossRef] [PubMed]

33. Huang, F.; Zhang, W.; Yue, E.; Liang, T.; Hu, X.; Sun, W.-H. Controlling the molecular weights of polyethylene waxes using the highly active precatalysts of 2-(1-aryliminoethyl)-9-arylimino5,6,7,8tetrahydrocycloheptapyridylcobalt chlorides: Synthesis, characterization, and catalytic behavior. Dalton Trans. 2016, 45, 657-666. [CrossRef] [PubMed]

34. Zhang, R.; Huang, Y.; Solan, G.A.; Zhang, W.; Hu, X.; Hao, X.; Sun, W.-H. Gem-Dimethyl-substituted bis(imino)dihydroquinolines as thermally stable supports for highly active cobalt catalysts that produce linear PE waxes. Dalton Trans. 2019, in press. [CrossRef]

35. Guo, J.; Wang, Z.; Zhang, W.; Oleynik, I.I.; Vignesh, A.; Oleynik, I.V.; Hu, X.; Sun, Y.; Sun, W.-H. Highly linear polyethylenes achieved using thermo-stable and efficient cobalt precatalysts bearing carbocyclic-fused NNN-pincer ligand. Molecules 2019, 24, 1176. [CrossRef] [PubMed] 
36. Yu, J.; Liu, H.; Zhang, W.; Hao, X.; Sun, W.H. Access to highly active and thermally stable iron precatalysts using bulky 2-[1-(2,6-dibenzhydryl-4-methylphenylimino)ethyl]-6-[1-(arylimino)ethyl]pyridine ligands. Chem. Commun. 2011, 47, 3257-3259. [CrossRef]

37. Cao, X.; He, F.; Zhao, W.; Cai, Z.; Hao, X.; Shiono, T.; Redshaw, C.; Sun, W.-H. 2-[1-(2,6-Dibenzhydryl-4chlorophenylimino)ethyl]-6-[1-(arylimino)ethyl]pyridyliron(II) dichlorides: Synthesis, characterization and ethylene polymerization behavior. Polymer 2012, 53, 1870-1880. [CrossRef]

38. Zhao, W.; Yu, J.; Song, S.; Yang, W.; Liu, H.; Hao, X.; Redshaw, C.; Sun, W.-H. Controlling the ethylene polymerization parameters in iron pre-catalysts of the type 2-[1-(2,4-dibenzhydryl-6-methylphenylimino) ethyl]-6-[1-(arylimino)ethyl] pyridyliron dichloride. Polymer 2012, 53, 130-137. [CrossRef]

39. Wang, S.; Li, B.; Liang, T.; Redshaw, C.; Li, Y.; Sun, W.-H. Synthesis, characterization and catalytic behavior toward ethylene of 2-[1-(4,6-dimethyl-2-benzhydrylphenylimino)ethyl]-6-[1-(arylimino)ethyl]- pyridylmetal (iron or cobalt) chlorides. Dalton Trans. 2013, 42, 9188-9197. [CrossRef] [PubMed]

40. Sun, W.-H.; Zhao, W.; Yu, J.; Zhang, W.; Hao, X.; Redshaw, C. Enhancing the Activity and Thermal Stability of Iron Precatalysts Using 2-(1-\{2,6-bis[bis(4fluorophenyl)methyl]-4-methylphenylimino\} ethyl)-6-[1-(arylimino)ethyl]pyridines. Macromol. Chem. Phys. 2012, 213, 1266-1273. [CrossRef]

41. Zhao, W.; Yue, E.; Wang, X.; Yang, W.; Chen, Y.; Hao, X.; Cao, X.; Sun, W.H. Activity and Stability Spontaneously Enhanced Toward Ethylene Polymerization by Employing 2-(1-(2,4-Dibenzhydrylnaphthylimino) Ethyl)-6-(1-(Arylimino)Ethyl) Pyridyliron(II) Dichlorides. J. Polym. Sci. Part A Polym. Chem. 2017, 55, 988-996. [CrossRef]

42. Yu, J.; Huang, W.; Wang, L.; Redshaw, C.; Sun, W.H. 2-[1-(2,6-Dibenzhydryl-4-methylphenylimino)ethyl]6-[1-(arylimino)ethyl]pyridylcobalt(II) dichlorides: Synthesis, characterization and ethylene polymerization behavior. Dalton Trans. 2011, 40, 10209-10214. [CrossRef] [PubMed]

43. He, F.; Zhao, W.; Cao, X.-P.; Liang, T.; Redshaw, C.; Sun, W.-H. 2-[1-(2,6-dibenzhydryl-4-chlorophenylimino)ethyl]6-[1-aryliminoethyl]pyridyl cobalt dichlorides: Synthesis, characterization and ethylene polymerization behavior. J. Organomet. Chem. 2012, 713, 209-216. [CrossRef]

44. Wang, S.; Zhao, W.; Hao, X.; Li, B.; Redshaw, C.; Li, Y.; Sun, W.-H. 2-(1-\{2,6-Bis[bis(4-fluorophenyl)methyl]4-methylphenylimino\}ethyl)-6-[1(arylimino)ethyl]pyridylcobalt dichlorides: Synthesis, characterization and ethylene polymerization behavior. J. Organomet. Chem. 2013, 731, 78-84. [CrossRef]

45. Lai, J.; Zhao, W.; Yang, W.; Redshaw, C.; Liang, T.; Liu, Y.; Sun, W.-H. 2-[1-(2,4-Dibenzhydryl-6methylphenylimino)ethyl]-6-[1-(arylimino)ethyl] pyridylcobalt(II) dichlorides: Synthesis, characterization and ethylene polymerization behavior. Polym. Chem. 2012, 3, 787-793. [CrossRef]

46. Zhang, W.; Wang, S.; Du, S.; Guo, C.-Y.; Hao, X.; Sun, W.-H. 2-(1-(2,4-Bis((di(4-fl uorophenyl)methyl)6methylphenylimino)ethyl)-6-(1-(arylimino) ethyl)pyridylmetal (iron or cobalt) Complexes: Synthesis, Characterization, and Ethylene Polymerization Behavior. Macromol. Chem. Phys. 2014, 215, 1797-1809. [CrossRef]

47. Mitchell, N.E.; Anderson, W.C., Jr.; Long, B.K. Mitigating Chain-Transfer and Enhancing the Thermal Stability of Co-Based Olefin Polymerization Catalysts through Sterically Demanding Ligands. J. Polym. Sci. Part A Polym. Chem. 2017, 55, 3990-3995. [CrossRef]

48. Huang, C.; Huang, Y.; Ma, Y.; Solan, G.A.; Sun, Y.; Hu, X.; Sun, W.H. Cycloheptyl-fused N,N,N'-chromium catalysts with selectivity for vinyl-terminated polyethylene waxes: Thermal optimization and polymer functionalization. Dalton Trans. 2018, 47, 13487-13497. [CrossRef]

49. Suo, H.; Oleynik, I.I.; Bariashir, C.; Oleynik, I.V.; Wang, Z.; Solan, G.A.; Ma, Y.; Liang, T.; Sun, W.-H. Strictly linear polyethylene using Co-catalysts chelated by fused bis(arylimino)pyridines: Probing ortho-cycloalkyl ring-size effects on molecular weight. Polymer 2018, 149, 45-54. [CrossRef]

50. Wang, Z.; Solan, G.A.; Mahmood, Q.; Liu, Q.; Ma, Y.; Hao, X.; Sun, W.-H. Bis(imino)pyridines Incorporating Doubly Fused Eight-Membered Rings as Conformationally Flexible Supports for Cobalt Ethylene Polymerization Catalysts. Organometallics 2018, 37, 380-389. [CrossRef]

51. Guo, L.; Zhu, D.; Zhang, W.; Zada, M.; Solan, G.A.; Hao, X.; Sun, W.-H. Remote dibenzocycloheptylsubstitution of an iminotrihydroquinolinenickel catalyst as a route to narrowly dispersed branched polyethylene waxes with alkene functionality. Eur. Polym. J. 2018, 107, 315-328. [CrossRef]

52. Mahmood, Q.; Zeng, Y.; Wang, X.; Sun, Y.; Sun, W.-H. Advancing polyethylene properties by incorporating $\mathrm{NO}_{2}$ moiety in 1,2-bis(arylimino)acenaphthylnickel precatalysts: Synthesis, characterization and ethylene polymerization. Dalton Trans. 2017, 46, 6934-6947. [CrossRef] [PubMed] 
53. Meiries, S.; Speck, K.; Cordes, D.B.; Slawin, A.M.Z.; Nolan, S.P. [Pd(IPr*OMe)(acac)Cl]: Tuning the N-Heterocyclic Carbene in Catalytic C-N Bond Formation. Organometallics 2012, 32, 330-339. [CrossRef]

54. Zada, M.; Guo, L.; Zhang, R.; Zhang, W.; Ma, Y.; Solan, G.A.; Sun, Y.; Sun, W.-H. Moderately branched ultra-high molecular weight polyethylene by using $\mathrm{N}, \mathrm{N}^{\prime}$-nickel catalysts adorned with sterically hindered dibenzocycloheptyl groups. Appl. Organomet. Chem. 2019, 33, e4749. [CrossRef]

55. Guo, L.; Zada, M.; Zhang, W.; Vignesh, A.; Zhu, D.; Ma, Y.; Liang, T.; Sun, W.-H. Highly linear polyethylenes tailored by 2,6-bis [1-(p-dibenzocycloheptylarylimino)ethyl]pyridylcobalt dichlorides. Dalton Trans 2019, 48, 5604-5613. [CrossRef] [PubMed]

56. Britovsek, G.J.P.; Bruce, M.; Gibson, V.C.; Kimberley, B.S.; Maddox, P.J.; Mastroianni, S.; McTavish, S.J.; Redshaw, C.; Solan, G.A.; Stromberg, S.; et al. Iron and Cobalt Ethylene Polymerization Catalysts Bearing 2,6-Bis(Imino)Pyridyl Ligands: Synthesis, Structures, and Polymerization Studies. J. Am. Chem. Soc. 1999, 121, 8728-8740. [CrossRef]

57. Britovsek, G.J.P.; Gibson, V.C.; Spitzmesser, S.K.; Tellmann, K.P.; White, A.J.P.; Williams, D.J. Cationic 2,6-bis(imino)pyridine iron and cobalt complexes: Synthesis, structures, ethylene polymerisation and ethylene/polar monomer co-polymerisation studies. J. Chem. Soc. Dalton Trans. 2002, 6, 1159-1171. [CrossRef]

58. Cantalupo, S.A.; Ferreira, H.E.; Bataineh, E.; King, A.J.; Petersen, M.V.; Wojtasiewicz, T.; DiPasquale, A.G.; Rheingold, A.L.; Doerrer, L.H. Synthesis with Structural and Electronic Characterization of Homoleptic Fe(II)- and Fe(III)-Fluorinated Phenolate Complexes. Inorg. Chem. 2011, 50, 6584-6596. [CrossRef]

59. Addison A., W.; Rao, T.N. Synthesis, Structure, and Spectroscopic Properties of Copper(II) Compounds containing Nitrogen-Sulphur Donor Ligands; the Crystal and Molecular Structure of Aqua[1,7-bis(Nmethylbenzimidazol-2'-yl)2,6-dithiaheptane]copper(ii) Perchlorate. J. Chem. Soc. Dalton Trans. 1984, 7, 1349-1356. [CrossRef]

60. Yuan, J.; Shi, W.-B.; Kou, H.-Z. Syntheses, crystal structures and magnetism of azide-bridged five-coordinate binuclear nickel(II) and cobalt(II) complexes. Transition Met. Chem. 2015, 40, 807-811. [CrossRef]

61. Britovsek, G.J.P.; Gibson, V.C.; Hoarau, O.D.; Spitzmesser, S.K.; White, A.J.P.; Williams, D.J. Iron and Cobalt Ethylene Polymerization Catalysts: Variations on the Central Donor. Inorg. Chem. 2003, 42, 3454-3465. [CrossRef]

62. Tomov, A.K.; Gibson, V.C.; Britovsek, G.J.P.; Long, R.J.; Meurs, M.V.; Jones, D.J.; Tellmann, K.P.; Chirinos, J.J. Distinguishing Chain Growth Mechanisms in Metal-catalyzed Olefin Oligomerization and Polymerization Systems: $\mathrm{C}_{2} \mathrm{H}_{4} / \mathrm{C}_{2} \mathrm{D}_{4}$ Co-oligomerization/Polymerization Experiments Using Chromium, Iron, and Cobalt Catalysts. Organometallics 2009, 28, 7033-7040. [CrossRef]

63. Barbaro, P.; Bianchini, C.; Giambastiani, G.; Rios, I.G.; Meli, A.; Oberhauser, W.; Segarra, A.M.; Sorace, L.; Toti, A. Synthesis of New Polydentate Nitrogen Ligands and Their Use in Ethylene Polymerization in Conjunction with Iron(II) and Cobalt(II) Bis-halides and Methylaluminoxane. Organometallics 2007, 26, 4639-4651. [CrossRef]

64. Pooter, M.D.; Smith, P.B.; Dohrer, K.K.; Bennett, K.F.; Meadows, M.D.; Smith, C.G.; Schouwenaars, H.P.; Geerards, R.A. Determination of the Composition of Common linear low Density Polyethylene Copolymers by 13C-NMR Spectroscopy. J. App. Polym. Sci. 1991, 42, 399-408. [CrossRef]

65. Galland, G.B.; Quijada, R.; Rojas, R.; Bazan, G.; Komon, Z.J.A. NMR Study of Branched Polyethylenes Obtained with Combined Fe and Zr Catalysts. Macromolecules 2002, 35, 339-345. [CrossRef]

66. Hansen, E.W.; Blom, R.B.; Bade, O.M.N.m.r. characterization of polyethylene with emphasis on internal consistency of peak intensities and estimation of uncertainties in derived branch distribution numbers. Polymer 1997, 38, 4295-4304. [CrossRef]

67. Sheldrick, G.M. Crystal structure refinement with SHELXL. Acta Crystallogr. C Struct Chem. 2015, 71, 3-8. [CrossRef] [PubMed]

68. Sheldrick, G.M. SHELXT-Integrated space-group and crystal structure determination. Acta Crystallogr. A Found Adv. 2015, 71, 3-8. [CrossRef] [PubMed]

Sample Availability: Samples of the organic compounds and cobalt complexes are available from the authors. 